\title{
Combustion, Pyrolysis, and Gasification of Waste-Derived Fuel Slurries, Low-Grade Liquids, and High-Moisture Waste: Review
}

\author{
Ksenia Vershinina (D), Galina Nyashina and Pavel Strizhak *(D) \\ Heat and Mass Transfer Laboratory, National Research Tomsk Polytechnic University, 30 Lenin Avenue, \\ 634050 Tomsk, Russia; vershininaks@gmail.com (K.V.); gsn1@tpu.ru (G.N.) \\ * Correspondence: pavelspa@tpu.ru; Tel.: +7-(3822)-701-777 (ext. 1910)
}

Citation: Vershinina, K.; Nyashina, G.; Strizhak, P. Combustion, Pyrolysis, and Gasification of Waste-Derived Fuel Slurries, Low-Grade Liquids, and High-Moisture Waste: Review. Appl. Sci. 2022, 12, 1039. https://doi.org/ 10.3390/app12031039

Academic Editor: Janusz Lasek

Received: 23 December 2021

Accepted: 17 January 2022

Published: 20 January 2022

Publisher's Note: MDPI stays neutral with regard to jurisdictional claims in published maps and institutional affiliations.

Copyright: (C) 2022 by the authors. Licensee MDPI, Basel, Switzerland. This article is an open access article distributed under the terms and conditions of the Creative Commons Attribution (CC BY) license (https:// creativecommons.org/licenses/by/ $4.0 /)$.

\begin{abstract}
The article discusses the modern achievements in the field of thermal recovery of industrial and municipal waste. The average accumulation rate and calorific value of typical wastes were analyzed. The focus is on the opportunities to exploit the energy potential of high-moisture waste, low-grade liquid components, and fuel slurries. We consider the relevant results in the field of combustion, pyrolysis, and gasification of such fuels. The main attention is paid to synergistic effects, the influence of additives, and external conditions on the process performance. Vortex combustion chambers, boilers with burners, and nozzles for fuel injection, grate, and fluidized bed boilers can be used for the combustion of waste-derived liquid, high-moisture, and slurry fuels. The following difficulties are possible: long ignition delay, incomplete combustion, low combustion temperature and specific calorific value, high emissions (including particulate matter, polycyclic aromatic hydrocarbons), fast slagging, and difficult spraying. A successful solution to these problems is possible due to the use of auxiliary fuel; boiler modifications; oxy-fuel combustion; and the preparation of multi-component fuels, including the use of additives. An analysis of methods of waste recovery in the composition of slurries for fuel gas production showed that there are several main areas of research: pyrolysis and gasification of coal-water slurry with additives of oil waste; study of the influence of external conditions on the characteristics of final products; and the use of specialized additives and catalysts to improve the efficiency of the pyrolysis and gasification. The prospects for improving the characteristics of thermochemical conversion of such fuels are highlighted.
\end{abstract}

Keywords: waste-to-energy; industrial and municipal waste; slurry; combustion; pyrolysis; gasification

\section{Introduction}

The problems of the annual formation of industrial waste are common to a wide group of industries, particularly chemical, petrochemical, coal, gas, and wood processing [1-3]. The most typical wastes of these industries are coal tar, waste oils, oil sludge, filter cakes, coal slime, sawdust, wood shavings, etc. [4-6]. Most of these materials and components pose a significant environmental threat. Waste occupies large areas and penetrates soil and water; gradual thermochemical transformation of waste is accompanied by the release of hazardous substances $[7,8]$. The most common methods of industrial waste disposal are the following [9-11]: burial, removal of impurities, storage, and reuse for its intended purpose, use as secondary raw material in oil refining and coal preparation, pelletizing, pyrolysis, gasification, and combustion. Most of the treatment and cleaning methods are quite ineffective for large volumes of industrial waste $[5,9,10]$. At the same time, many enterprises are forced to incur heavy losses due to environmental fines [12] associated with ineffective waste disposal or its absence. Disruptive technologies are required for efficient waste disposal. However, their creation and adaptation require significant economic costs at the initial stage.

Municipal waste is no less dangerous for humanity. In terms of component composition, accumulated volumes, and rates of annual formation, they are practically not 
inferior to industrial ones [13]. In countries with undeveloped economies, municipal solid waste is considered even more hazardous than industrial waste. The most typical municipal solid waste includes cardboard, paper, plastic, polyethylene, rubber, food debris, etc. $[14,15]$. Landfilling, thermal treatment, and incineration with energy generation are popular disposal methods for such waste [16-18]. Holubčík et al. [19] used slow pyrolysis of shredded used car tires and plastic packaging. The research [19] has confirmed that pyrolysis allows for the production of valuable products with minimal damage to the environment. Bala-Litwiniak and Radomiak [20] have shown that waste glycerol can be successfully used as a fuel in combination with wood pellets. Glycerin with a fraction of no more than $4.5 \%$ improved the quality of the pellets and the environmental performance [20]. Dudyński et al. [21] carried out a test gasification of leather waste on a laboratory and industrial scale. As a result, a producer gas was obtained with a heating value of 4.1-6.5 MJ $/ \mathrm{m}^{3}$. Dudyński et al. [21] concluded that gasification of waste leather may be more promising than incineration, mainly due to greater environmental safety.

However, the rate of the annual increase in municipal waste is so high that the factories for their utilization manage to process no more than $20-30 \%$. The main difficulty lies in the need to sort waste to ensure high economic performance. Unfortunately, in many regions, management mechanisms and regulatory documents have not been formed for the effective separation of waste. As a result, numerous landfills increase in volume every year. Waste disposal technologies without preliminary sorting are important.

Analysis of the current state of utilization of industrial and municipal waste $[16,22]$ shows that technologies are required that allow for solving a set of problems. In particular, it is necessary, along with waste disposal, to effectively expand the raw material base, reduce the anthropogenic load on the environment, and increase the area for beneficial use. We need objective assessments of the totality of economic, environmental, energy, and social criteria and justification of the effectiveness of technologies, taking into account all the main categories (for example, using methods of multiple-criteria decision analysis [23,24]). The development of universal technological solutions for preparing waste for incineration or deep conversion, storage, transportation under different climatic conditions, and spraying in combustion chambers is of current interest. To solve this kind of problem, it is important to analyze modern ideas about the relevant processes, including the results of experimental and theoretical studies of the world scientific community. To date, a large experimental base has been obtained $[25,26]$ and the results of mathematical modeling $[27,28]$, which develop ideas from reviews [29-31] and books [32,33].

The purpose of this review article is to draw the attention of readers to the problems of recovery of industrial and municipal waste, as well as to substantiate the prospects of certain solutions to these problems.

\section{Main Types of Combustible Waste}

The annual world production of waste is at least 4500 million tons. Among the main sources of waste are the following: (i) energy sector (waste from the production, processing, and combustion of fuels); (ii) industry (waste oils and chemicals, machines and mechanisms) municipal sector (solid waste, sewage sludge, construction waste); woodworking and agricultural sector (sawmill waste, woodworking, agricultural waste, etc.). Each of the listed categories of waste contains wastes that are suitable for the preparation of mixed and slurry fuels (Figure 1).

Coal of different grade $[38,39]$ and coal slimes $[40,41]$ can be used as basic components. The water of different quality (polluted or purified) [42], wastewater [43], and industrial water [38] can be used as a dispersed medium. Additional components (usually in a small amount of 5-20 wt\%) can be the following: oil sludge [44,45], used automotive and industrial oils [39,46], alcohols [47,48], and biomass [46,49]. Such additives are used to improve the ignition and combustion performance of the fuel, increase its calorific value, and reduce emissions. Solid components can be torrefied to improve efficiency. This method is a promising thermochemical technology for converting solid feedstock (most 
often biomass) into biochar for co-combustion [50,51] or for pyrolysis or gasification [52,53] Torrefaction is defined as thermal treatment in an inert environment at atmospheric pressure and temperatures within the range of $200-300{ }^{\circ} \mathrm{C}$. The main principles of torrefaction are to remove oxygen, reduce moisture content, and produce a solid residue that has a lower $\mathrm{O} / \mathrm{C}$ ratio than the feedstock. The main purpose of torrefaction is to increase the calorific value. The main product of torrefaction is solid biochar (up to $80 \mathrm{wt} \%$ of feedstock) [52].

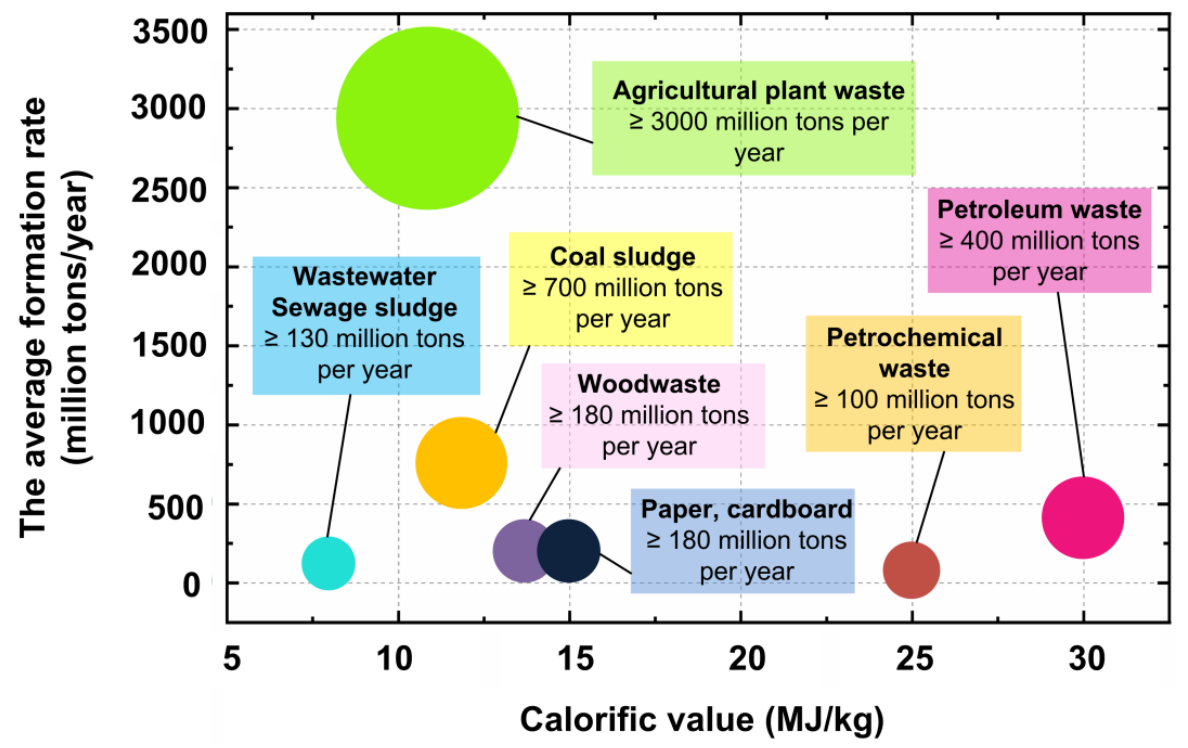

Figure 1. Calorific value of wastes and their average global generation rate (according to [13,34-37]).

Table 1 provides a list of typical components used to create fuel slurries and blends.

Table 1. Properties of the components used for the preparation of fuel mixtures.

\begin{tabular}{|c|c|c|c|c|c|c|c|c|c|c|c|}
\hline \multirow[b]{2}{*}{ Component } & \multicolumn{5}{|c|}{ Ultimate Analysis (wt \%) } & \multicolumn{5}{|c|}{ Proximate Analysis (wt $\%$ ) } & \multirow[b]{2}{*}{ Ref. } \\
\hline & $\mathrm{C}$ & $\mathbf{H}$ & $\mathbf{O}$ & $\mathbf{N}$ & S & Moisture & $\begin{array}{l}\text { Volatile } \\
\text { Matter }\end{array}$ & $\begin{array}{c}\text { Fixed } \\
\text { Carbon }\end{array}$ & Ash & $\begin{array}{l}\text { Calorific Value } \\
(\mathrm{MJ} / \mathrm{kg})\end{array}$ & \\
\hline Shenhua coal & 69.55 & 3.74 & 10.14 & 0.83 & 0.25 & 8.28 & 29.55 & 54.96 & 7.21 & 27.07 & [38] \\
\hline Samca coal & 75.9 & 5.3 & 12.27 & 0.7 & 5.8 & - & 36.9 & - & 22.8 & - & [39] \\
\hline Coal gangue & 17.5 & 1.26 & - & 0.56 & 1.28 & 0.75 & 15.07 & 16.31 & 68.62 & 4.82 & [40] \\
\hline Coal slime & 87.2 & 5.1 & 4.5 & 2.1 & 1.1 & - & 23.1 & - & 26.5 & 24.83 & [41] \\
\hline Semicoke powders & 69.12 & 1.35 & 10.33 & 0.89 & 0.71 & 0.7 & 15.74 & 67.36 & 16.9 & - & [54] \\
\hline Pyrolytic carbon black & 93.5 & 2.84 & $<0.01$ & 0.46 & 3.2 & - & - & - & 25 & 26 & [55] \\
\hline Textile dyeing sludge & 15.53 & 3.44 & 16.47 & 2.43 & 1.38 & 1.37 & 36.53 & 1.35 & 60.75 & 5.99 & [56] \\
\hline Waste soot & 74.6 & 1.6 & - & 0.2 & 1.35 & 68.6 & - & - & - & 28.1 & [57] \\
\hline Sewage sludge & 24.83 & 3.31 & 14.39 & 4.47 & 1.13 & 97.95 & 42.74 & 5.39 & 44.58 & 0.77 & [58] \\
\hline Sewage sludge & 13.22 & 2.91 & 19.7 & 2.12 & 0.57 & 5.29 & 31.31 & 2.06 & 61.34 & 5.215 & [59] \\
\hline Coking sludge & 24.48 & 3.15 & 23.68 & 2.36 & 0.94 & 78.97 & 45.48 & 9.14 & 45.38 & 8.49 & [60] \\
\hline Brewery wastewater sludge & 17.6 & 2.93 & - & 2.41 & - & 2.33 & 37.72 & 0.09 & 59.86 & 6.56 & [61] \\
\hline Waste lubricating oil & 83.53 & 13.32 & 2.83 & 0.15 & 0.17 & - & - & - & - & - & [62] \\
\hline Mineral waste oil & 83.2 & 13.0 & 1.2 & - & 1.2 & - & - & & - & - & [39] \\
\hline Lubricating Oil Wastes & 83.2 & 13 & 1.2 & - & 1.2 & - & - & - & - & 44.33 & [63] \\
\hline Waste lubricating oil & 84.02 & 13.31 & 1.92 & - & 0.75 & - & - & - & - & - & {$[46]$} \\
\hline Waste cooking oil & 71.84 & 10.14 & 17.71 & 0.06 & 0.01 & 0.08 & 99.15 & 0.56 & 0.24 & 39.24 & [64] \\
\hline Oily sludge & 63.9 & 7.3 & 25.3 & 1.2 & 2.3 & 33.4 & 69.3 & - & 21.2 & 23 & [44] \\
\hline
\end{tabular}


Table 1. Cont.

\begin{tabular}{|c|c|c|c|c|c|c|c|c|c|c|c|}
\hline \multirow[b]{2}{*}{ Component } & \multicolumn{5}{|c|}{ Ultimate Analysis (wt \%) } & \multicolumn{5}{|c|}{ Proximate Analysis (wt $\%$ ) } & \multirow[b]{2}{*}{ Ref. } \\
\hline & $\mathrm{C}$ & $\mathbf{H}$ & $\mathbf{O}$ & $\mathbf{N}$ & S & Moisture & $\begin{array}{l}\text { Volatile } \\
\text { Matter }\end{array}$ & $\begin{array}{c}\text { Fixed } \\
\text { Carbon }\end{array}$ & Ash & $\begin{array}{c}\text { Calorific Value } \\
\text { (MJ/kg) }\end{array}$ & \\
\hline Bio-oil (from pyrolysis of pine) & 41.47 & 6.37 & 52.05 & 0.11 & - & 24.7 & 73.1 & 2.1 & 0.1 & 16.9 & [65] \\
\hline Corn stalk & 32.01 & 3.44 & 24.0 & 1.02 & 0.22 & 6.77 & 52.1 & 8.61 & 32.52 & 11.87 & [66] \\
\hline Coal slime & 53.29 & 3.89 & 9.41 & 0.83 & 0.65 & 0.95 & 27.51 & 36.62 & 34.92 & 22.07 & [59] \\
\hline Bamboo residual & 55.51 & 6.12 & 42.05 & 0.21 & 0.11 & - & - & - & - & - & {$[46]$} \\
\hline Corn silage & 43.40 & 6.17 & 46.70 & 1.02 & 0.93 & - & - & - & - & - & [67] \\
\hline Clover grass & 44.90 & 6.8 & 43.30 & 2.2 & 0.3 & - & - & - & - & - & [67] \\
\hline Biochar (from pyrolysis of pine) & 86.83 & 3.34 & 9.7 & 0.13 & - & 2.4 & 16.4 & 80.6 & 3.0 & 28.3 & [65] \\
\hline
\end{tabular}

\section{Combustion of Non-Conventional Liquid, High-Moisture, and Slurry Fuels}

Most studies on the incineration of waste and low calorific fuels involve the use of solid, specially treated, and dehydrated components (for example, $[6,49,68]$ ). Co-firing of coal and biomass [69], as well as the individual firing of biomass, are most actively studied. This is partly because the energy use of biomass is already reaching an industrial level in many countries and requires large-scale tests [69,70]. To study the individual and co-combustion of biomass and solid waste, quite a few types of plants are used, including reactors and furnaces of both laboratory [71] and pilot scale [72]. The number of papers on the regularities of combustion of liquid fuels (oils, slurries, and emulsions based on waste) is much less. In this review, we focus on the results of current research in the field of waste incineration, predominantly in liquid and slurry form or with high moisture content. This direction is quite promising, as it allows expanding the fuel component base and obtaining environmental benefits.

When studying the thermal properties of mixed fuels and individual components, standard methods are widely used (thermogravimetric analysis, calorimetry, spectrometry, etc.). The characteristics of ignition and burnout of fuels, depending on the research objectives, are studied using installations of various types and power (some typical examples are given in Table 2).

Table 2. Experimental plants for the study of ignition and combustion of non-conventional fuels.

\begin{tabular}{|c|c|c|c|}
\hline Fuel & Installation & Temperature Conditions & Ref. \\
\hline $\begin{array}{l}\text { Stem wood, bark, forest residue, willow, } \\
\text { and reed canary grass and pyrolysis oil } \\
\text { and solid residue from them }\end{array}$ & $\begin{array}{l}\text { Tube furnace blown by gas } \\
\text { mixtures (air, } \mathrm{N}_{2}, \mathrm{O}_{2} \text { ) }\end{array}$ & $<1400^{\circ} \mathrm{C}$ & [73] \\
\hline $\begin{array}{l}\text { Emulsion based on water and heating oil; } \\
\text { slurry based on water and pyrolytic soot }\end{array}$ & $\begin{array}{l}\text { Chamber with industrial burners } \\
\text { with a total power of } 1.2 \mathrm{MW}\end{array}$ & $\begin{array}{c}\text { Temperature of flue gases } \\
>1100^{\circ} \mathrm{C} \\
\text { Maximum operating temperature } \\
1430{ }^{\circ} \mathrm{C}\end{array}$ & [55] \\
\hline $\begin{array}{l}\text { Spherical particles of corn stalk and } \\
\text { bituminous coal }\end{array}$ & $\begin{array}{l}\text { Reactor (electrical quartz tube), } \\
\text { blown by mixtures of } \mathrm{O}_{2} / \mathrm{N}_{2} \text { and } \\
\qquad \mathrm{O}_{2} / \mathrm{H}_{2} \mathrm{O}\end{array}$ & $800^{\circ} \mathrm{C}$ & [66] \\
\hline $\begin{array}{l}\text { Sewage sludge with coal-water slurry } \\
\text { (CWS) }\end{array}$ & $\begin{array}{l}\text { Large scale fluidized bed } \\
\text { incinerator }\end{array}$ & $>1000^{\circ} \mathrm{C}$ & [58] \\
\hline Wet sewage sludge with wood chips & $\begin{array}{l}\text { Grate-fired boiler with a vibrating } \\
\text { grate }\end{array}$ & $>1000^{\circ} \mathrm{C}$ & [74] \\
\hline $\begin{array}{l}\text { Pyrolysis oil from sewage sludge, heavy } \\
\text { fuel oil }\end{array}$ & $\begin{array}{l}\text { Laboratory setup with heat } \\
\text { sources in the form of two plates }\end{array}$ & $\begin{array}{l}\text { Temperature of the plates is } 500 \\
\qquad 550,600^{\circ} \mathrm{C}\end{array}$ & {$[60]$} \\
\hline
\end{tabular}


Table 2. Cont.

\begin{tabular}{cccc}
\hline Fuel & Installation & Temperature Conditions & Ref. \\
\hline $\begin{array}{c}\text { Slurry based on coal, water and waste } \\
\text { soot }\end{array}$ & Rotary kiln & $800{ }^{\circ} \mathrm{C}$ & {$[57]$} \\
\hline $\begin{array}{c}\text { Slurries based on coal and liquid waste } \\
\text { from petrochemical industry }\end{array}$ & Pilot-scale combustion system & $\begin{array}{c}1100-1300^{\circ} \mathrm{C} \text { at steady } \\
\text { combustion }\end{array}$ \\
\hline
\end{tabular}

\subsection{Influence of the Composition of the Oxidizing Atmosphere on the Ignition and Combustion}

When burning low-grade mixed fuels, it is important to select the optimal ratio of components and the operating mode of technological equipment. It is known that ignition and combustion can be significantly improved by varying the composition of the oxidizing medium [76,77]. For low-grade fuels with high moisture and ash content, this approach can be promising. This is confirmed by Gaber et al. in the study [55], where water-oil emulsions and coal-water slurries were burned in an environment enriched with oxygen (from $50 \%$ to $100 \%$ ) at high temperatures in a chamber with industrial burners. These conditions are used to improve the combustibility and combustion efficiency of fuels with high water content. The slurry was prepared on the basis of water and pyrolytic carbon black (a tire pyrolysis product), which is difficult for direct disposal due to its high sulfur content [55]. Gaber et al. [55] found that it is important to use finely divided particles of pyrolytic carbon black for complete burnout of the slurry. The high share of water in the prepared mixtures $(75 \%$ in the emulsion and $65 \%$ in the slurry) did not lead to combustion failure and contributed to a multiple decrease in $\mathrm{NO}_{\mathrm{x}}$ and $\mathrm{CO}$ emissions with a moderate decrease in the combustion temperature. Gaber et al. [55] concluded that, with a high $\mathrm{O}_{2}$ content (50-100\%), it is not necessary to additionally burn natural gas for the combustion of the slurry to be stable. It was also found that the oxygenated reagent can be used only as a spray gas, but in this case the thermal efficiency will be lower than when using oxy-fuel combustion.

It is interesting to note that the $\mathrm{O}_{2}$ proportion in the oxidizing atmosphere can have an ambiguous effect on the combustion efficiency of composite fuels. For example, Chansa et al. [78] performed a thermogravimetric analysis of the co-firing of lignite and corn straw while varying the proportion of biomass (28-40\%) and oxygen (20-80\%). Thermograms and the calculated combustion index showed that the proportion of straw has practically no effect on the combustion efficiency, in contrast to the oxygen content. At the same time, the oxygen saturation above $60 \%$ led to a decrease in the combustion index. The combustion index is often used by researchers when analyzing thermogravimetric results. Combustion index is a value calculated using thermogravimetric curves. The formula for calculating the combustion index can vary to a limited extent in different studies. However, the basic concept assumes the use of such quantities as the rate of weight loss during sample combustion (maximum and/or average), ignition temperature, and burnout temperature. In general terms, the combustion index is a fraction, in the numerator of which the product of the maximum and average rate of mass loss, in the denominator-the product of the ignition temperature squared and the burnout temperature. The higher this index, the more intensively the combustion of the sample proceeds.

Johansson et al. [73] studied the combustion of woody biomass and the products of its pyrolysis (bio-oils and biochar). Fuels were burned in a tube furnace in a normal atmosphere and with an oxygen excess $\left(40 \%\right.$ and $\left.60 \% \mathrm{O}_{2}\right)$. The bio-oils were pre-mixed with methanol $(40 \mathrm{wt} \%)$ to lower the viscosity to facilitate atomization in the furnace. It was found that oxygen saturation had an insignificant effect on the emissions of inorganic substances during the combustion of bio-oils. The use of pyrolysis oil as a fuel makes it possible to reduce the number of solid particles in flue gases (up to 100 times), but the size of the resulting particles will be much larger than when burning the initial biomass. In general, Johansson et al. [73] recommended the liquid products of biomass pyrolysis for combustion in small boilers not loaded with specialized cleaning equipment, since such fuel will not cause major problems with slagging and ash removal. The solid residues 
of the woody biomass pyrolysis emit more solid particles during combustion and are more suitable for large boilers equipped with modern devices for cleaning flue gases and removing ash.

The use of an oxygen-water vapor medium can be a promising solution for efficient combustion of low-grade fuel mixtures. Zhou et al. [66] confirmed this experimentally when studying the ignition and combustion of individual particles of coal and biomass (corn stalks) in different oxidizing mediums $\left(\mathrm{O}_{2} / \mathrm{N}_{2}\right.$ and $\left.\mathrm{O}_{2} / \mathrm{H}_{2} \mathrm{O}\right)$. The study was carried out in a vertical tubular reactor using high-speed video recording and two-color pyrometer. It was found that replacing nitrogen with water vapor improves the combustion dynamics of biomass and coal particles. With an increase in the proportion of oxygen in the gas mixture up to $50 \%$ (in both atmospheres), the ignition delay times decreased by $\approx 30-40 \%$, the burnout time of volatiles decreased by $10-15 \%$, and the combustion temperature increased by $5-7 \%[66]$.

Thus, the results $[51,62,69,74]$ indicate the possibility of a significant improvement in the ignition and burnout performance of low-grade fuel mixtures due to the use of highly oxygenated reagents. At the same time, the requirements for the equipment and materials used will undoubtedly increase to ensure long-term and uninterrupted operation of the boiler (although, in general, the thermal stress of the boiler when burning waste is less than when burning high-energy fuels). More importantly, oxy-fuel combustion is an energy-consuming and expensive technology $[79,80]$. Conventional boilers must be extensively modified and the flue gases must be efficiently recirculated to achieve the required combustion performance. Additional operating costs are required including maintenance and operation of separation units for large-scale $\mathrm{O}_{2}$ production. Therefore, the prospects for the use of oxy-fuel combustion for waste-based blends should be analyzed in a comprehensive manner, considering commercial and technological limitations, as well as an assessment of the beneficial effect. For industrial applications, this technology is still poorly applicable, including due to the lack of some fundamental data on the combustion of waste-derived fuels (including conversion of chemicals, corrosive properties, ash behavior, etc.).

\subsection{Synergism of Components at Ignition and Burnout of Composite Fuels}

The issue of choosing the ratio of the components in the fuel mixture is very relevant for researchers. This is important since even small changes in the component composition of the fuel can lead to both positive and negative consequences during combustion. When mixing components of different origins, synergies often arise. For example, Feng et al. [65] studied the combustion of bio-oil/biochar slurry in a drop tube furnace at $1400{ }^{\circ} \mathrm{C}$ to identify synergistic effects in the formation of $\mathrm{PM}_{10}$. For the preparation of slurries, bio-oil and biochar (pine pyrolysis products) were used. The proportion of biochar in the slurries was $5 \%$ and $10 \%$. Mixed fuels, as well as individual components, were fed into a tubular drip furnace and burned at $1400^{\circ} \mathrm{C}$. Particle matters were collected and analyzed. The calculated values of the yield of $\mathrm{PM}_{0.1-1}$ and $\mathrm{PM}_{1-10}$ differed from those established experimentally for two-phase mixtures, which indicates the synergism of the components. In particular, the emissions of $\mathrm{PM}_{0.1-1}$ were higher than the calculated ones, and the emissions of $\mathrm{PM}_{1-10}$ were lower than the calculated ones. Feng et al. [65] concluded that the two mechanisms operate simultaneously. The first mechanism is associated with the extraction of inorganic particles from biochar into bio-slurry; the second mechanism is due to the interaction of components during combustion (volatile oils contain reactive substances that activate the volatilization of inorganic particles of char). Synergistic interaction of components in slurry fuel during its combustion was also observed in the study [81]. Thermogravimetric analyzer STA409PG was used for studying the combustion characteristics of slurries derived from biomass, coal, and char. Bio-oil was produced by pyrolysis of fruit trees and mixtures of rice and straw. The share of bio-oil in the slurry varied in the range of $34-40 \%$. Characteristics were also obtained for samples of solid fuels-lignite, char, and long-flame coal. Feng et al. [81] noted a synergistic effect between bio-oil and coal or coke, resulting in improved 
combustion performance [81]. Presumably, the main reason was the catalytic activity of alkaline and alkaline earth elements contained in bio-oil, as well as micro-explosions. The change in the activation energy had a different character when using bio-oil of different origins. Lignite-based fuels had the lowest activation energy [81]. Feng et al. [81] concluded that the investigated slurries are applicable in the industry. Compared to coals and char, slurries based on coal and bio-oil have a lower combustion temperature and burnout time. Therefore, when they are burned, it is possible to reduce the requirements for the material of the inner surface of the boiler and use more compact combustion chambers [81].

Studies $[41,55,56]$ have shown that the synergism of the components during the combustion of low-grade fuel blends is manifested under certain conditions (the temperature in the chamber has a dominant effect). For example, Glushkov et al. [41] studied the ignition and combustion behavior of slurry droplets based on high-moisture coal waste, municipal solid waste, and waste oil when droplets are heated in a muffle furnace. Changes in the fuel composition (varying the proportion of municipal waste, adding oil) significantly affected the ignition characteristics in the temperature range $600-800{ }^{\circ} \mathrm{C}$, but with an increase in the heating temperature $\left(800-1000{ }^{\circ} \mathrm{C}\right)$, the ignition of fuels of different composition occurred with a very close time delay (the difference about $5 \%$ at $1000{ }^{\circ} \mathrm{C}$ ) [41]. Co-combustion of coal and additional components also provides beneficial effects but on a limited scale. This was confirmed, for example, in the study [59] during the combustion of dewatered sewage sludge and coal sludge in a thermogravimetric analyzer. Fu et al. concluded [59] that it is advisable to use sewage sludge to improve the combustion characteristics of coal waste. However, the synergistic effect was manifested only at low temperatures. It is important to take into account that, with an increase in temperature, negative effects arise, for example, the intensive formation of alkali metal aluminosilicates. This phenomenon can aggravate slagging of equipment surfaces during high-temperature incineration. In addition, an increase in the proportion of sewage sludge in the mixture (over 20\%) improved the ignition at the initial stage of heating but led to a decrease in the combustion intensity [59].

\subsection{Combustion of Wet Sludge, Process Fluids, and Waste Cooking Oils as Part of Fuel Mixtures}

In the field of waste-to-energy technologies, researchers are particularly interested in the possibility of using process and sewage sludge as fuel, since there are a lot of them, especially in large cities and industrial regions [59]. There is quite a lot of data on the combustion of sewage or technological sludge in a dry or treated state (for example, [82,83]), in contrast to studies where they are used in a high-moisture state or as part of liquid composite fuels. One of such studies is the work [58], in which sewage sludge and coal-water slurry were burned together in a reactor with a circulating fluidized bed. According to Zhao et al. [58], the use of wet sewage sludge as a part of fuel slurry may be one of the best solutions in terms of environmental benefits. Experiments have shown that the proportion of sewage sludge strongly affects the characteristics of the combustion. With a sewage sludge fraction of $20 \%$, the temperature in the fluidized bed dropped significantly but then gradually stabilized. With an increase in the sewage sludge proportion from $0 \%$ to $40 \%$, an increase in the emissions of polycyclic aromatic hydrocarbons (PAHs), polychlorinated biphenyls (PCBs), $\mathrm{NO}_{x}$, and a decrease in $\mathrm{SO}_{\mathrm{x}}$ emissions was observed [58]. The recommended fraction of sewage sludge is $20-30 \%$ [58], which allows for limiting the emissions of organic and inorganic pollutants within acceptable ranges. A similar conclusion regarding the proportion of sludge was reached by Luo et al. [61], who investigated the co-combustion of a wastewater sludge brewery and coal using thermogravimetry. The results showed that the proportion of wastewater sludge should not exceed $15 \%$. Above $15 \%$, the ignition temperature decreased, but negative effects had arisen-the overall combustion index and the burnout temperature decreased [61]. Lei et al. [82] studied the co-combustion of sewage sludge and coal in normal air and oxygenated air. An increase in the proportion of sewage sludge from $0 \%$ to $50 \%$ led to a decrease in the ignition delay time of volatiles and the burnout time of particles. The following effects were also recorded: an increase in the 
average flame temperature by $66.8^{\circ} \mathrm{C}$, a decrease in the size of the flame of the burning volatiles, and a decrease in the combustion temperature of solid particles by $191^{\circ} \mathrm{C}$.

Zhao et al. [43] used coking wastewater and coking sludge as components for the preparation of fuel slurries. The characteristics of coal-water slurry, coking wastewater-coal slurry, and coking sludge-coal slurry were compared [43]. The obtained thermogravimetric profiles for the three slurries were practically identical. According to the findings of Zhao et al. [43], the used coking sludge promotes combustion of the fuel slurry due to the presence of catalytic minerals. The slurry with the addition of coking wastewater had the highest burnout temperature $(868.63 \mathrm{~K})$ and the maximum combustion index. Due to the high content of ammonia nitrogen, the peak emissions of nitrogen oxide during the combustion of slurries with the addition of coking wastewater and coking sludge exceeded 1.5-2 times the emissions during combustion of the slurry based on coal [43]. However, ammonia was not detected in the flue gas. Sulfur dioxide emissions differed to a lesser extent. It was noted that the second peaks in the $\mathrm{SO}_{2}$-trends are lower for the slurries with the addition of waste. This may be because coke waste contains minerals that retain sulfur [43]. The ash residue of the slurry with the addition of waste contained less heavy metals than the residue of the coal-water slurry. Zhao et al. [43] noted that the result is most likely due to the presence of chlorine in the coking wastewater and the coking sludge, which, when heated, reacts with heavy metals and forms volatile chlorides.

Kuan et al. [60] investigated the joint and individual combustion of heavy fuel oil and pyrolysis oil obtained from sewage sludge. Thermogravimetric analysis of fuels was carried out, as well as their combustion in the form of single droplets. It was found that the addition of pyrolysis oil led to a decrease in the ignition temperature and an increase in temperature at the combustion stage. An increase in the proportion of oil (the range was $20-80 \%$ ) intensified micro-explosions of mixed fuel droplets and increased the burning rate. The negative effect was an increase in the ignition delay time due to an increase in the total moisture content of the fuel. In addition, Kuan et al. [60] found that the proportion of pyrolysis oil has little effect at the final stage of the combustion of the composite fuel when heavy components are burned out.

Waste cooking oils are one of the large categories of waste, typical for municipal areas. According to the report [84], in 2015, about $712 \mathrm{kt}$ of waste cooking oils were collected in Europe (excluding data from some countries). Without proper disposal, waste cooking oils represent a dangerous source of environmental pollution. Typically, waste cooking oils are considered as feedstock for the production of biofuels (biodiesel, biogas, and hydrogen gas), but can also be used as fuel for boilers. Gad et al. [85] investigated the spraying and combustion of waste cooking oil in a $500 \mathrm{~kW}$ industrial boiler. Compared to light diesel fuel, the cooking oil had a higher viscosity and a lower adiabatic flame temperature (the difference was $200-250{ }^{\circ} \mathrm{C}$ ). $\mathrm{CO}$ and $\mathrm{NO}_{\mathrm{x}}$ emissions from burning cooking oil were several times less than from burning diesel fuel. The emissions of unburned hydrocarbons from cooking oil were 2-4 times higher than from diesel fuel. Gad et al. [85] emphasized that many characteristics of both diesel fuel and waste cooking oil have been successfully improved through the use of additives. Chen et al. [86] studied the combustion characteristics of mixtures of waste cooking oil and diesel fuel. The proportion of cooking oil was $20 \%$ and $40 \%$. According to the results of the experiments, Chen et al. [86] found that the emissions of dioxins, furans, and polychlorinated biphenyls during the combustion of these mixtures are $26 \%$ and $86 \%$ lower in comparison with petroleum diesel fuel. Chen et al. [86] concluded that mixtures based on waste cooking oils are promising as an auxiliary fuel for a boiler that incinerates solid household waste. Ortner et al. [87] confirm that the energy recovery of waste cooking oils is one of the most beneficial strategies for their use. Ref. [87] considers three recovery scenarios: biogas production in an agricultural biogas plant, combustion in a cogeneration plant, and biodiesel production. All three approaches were recognized as environmentally promising since they reduce greenhouse gas emissions. Ortner et al. [87] concluded that the most efficient scenarios are the processing of waste cooking oils into biodiesel and use for the production of heat and electricity. 


\subsection{Combustion of Low-Grade Liquid, Wet, and Slurry Fuels in Large Experimental and Pilot-Scale Plants}

The experience of combustion of liquid, high-moisture and slurry fuels in large plants is relatively small today. The available research results $[51,53,70,71]$, as well as the experience of combustion of coal-water slurries $[88,89]$, allow us to conclude that vortex combustion chambers, boilers with burners and nozzles for fuel injection, grate, and fluidized bed boilers can used for industrial combustion of low-grade fuels with high moisture content (Figure 2).

\section{Combustion of low-grade liquid, high-moisture, and slurry fuels in large plants}

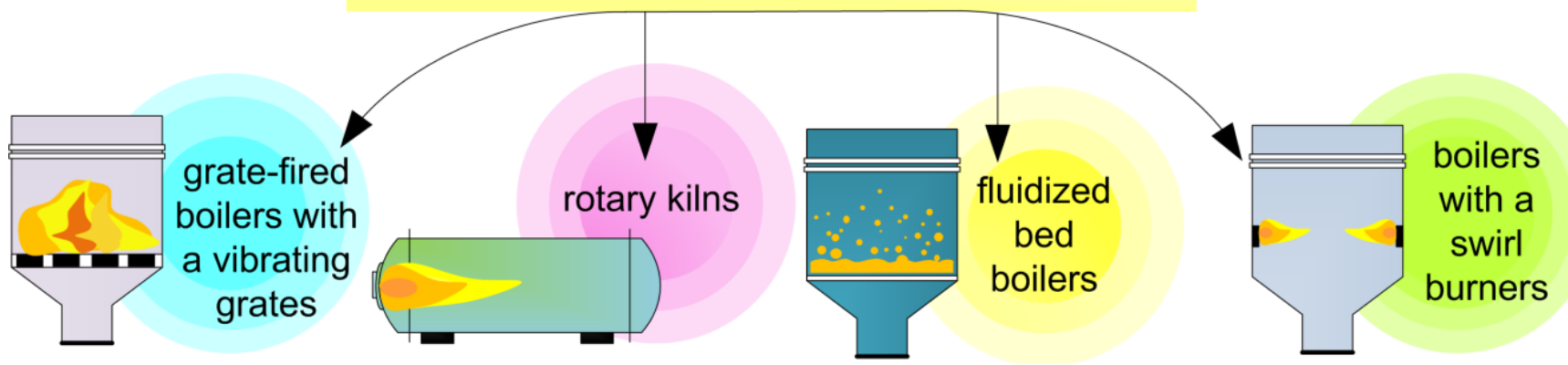

Figure 2. The main types of large plants used for the combustion of low-grade, high-moisture, and slurry fuels.

Skoglund et al. [74] carried out studies at an operating grate-fired boiler at a thermal power plant (Enköping in Sweden) with a capacity of $55 \mathrm{MW}$ of thermal energy and $24 \mathrm{MW}$ of electricity. The base fuel for the boiler was wood. In the experiment [74], a high-moisture sewage sludge (moisture content $76 \%$ ) was burned together with wood chips from the demolition of buildings. The proportion of the sewage sludge was $35 \%$ and $45 \%$. When testing new fuel, the boiler operated at $50 \%$ capacity. Compared to the combustion of wood chips, the mixture with sewage sludge produced more nitrogen oxides (a moderate increase relative to permissible levels) and sulfur oxides (a significant increase-at least by 8 times). Skoglund et al. [74] concluded that, for the combustion of such mixtures in the existing plant, it is necessary to further improve the flue gas condensation and $\mathrm{SO}_{2}$ removal. It was noted that the incineration of mixtures did not cause problems with slagging, contrary to expectations [74]. In the experiment, which lasted $12 \mathrm{~h}$, it was possible to provide the required boiler power by increasing the fuel consumption. In general, Skoglund et al. [74] assessed the experience gained as positive and concluded that the combustion of highmoisture mixtures with minimal preparation of sewage sludge can be considered successful in the existing boiler.

Jianzhong et al. [75] obtained important results on the combustion of fuel slurries based on coal and liquid waste from petrochemical production. The fuels were burned in a pilot-scale furnace with a slurry flow rate of up to $100 \mathrm{~kg} / \mathrm{h}$. To warm up the furnace to at least $500{ }^{\circ} \mathrm{C}$ and improve the ignition of the slurry, diesel fuel was used, the supply of which was stopped after the combustion stabilized. Compared to the conventional coal slurry (base on water), the slurries based on waste liquids exhibited a faster reaction rate at ignition. Jianzhong et al. [75] concluded that this result may be due to the fact that the petrochemical waste liquids contain volatile reactive components and metal ions, which catalyze the release of volatiles and burnout of coal particles. The combustion temperatures of the waste-based slurries were generally $50-100{ }^{\circ} \mathrm{C}$ higher than that of the conventional coal-water slurry. Analysis of unburned residues showed that the carbon content in them during the combustion of the slurries based on liquid waste is less than that of the slurry based on water. However, this difference leveled out in certain areas of the furnace and the carbon content in the residues reached $10-25 \%$ for all fuels. The combustion efficiency of 
waste-based slurry was higher than that of coal-water slurry and approached the efficiency of pulverized coal combustion. In this case, a negative effect was enhanced slagging due to the high content of alkaline earth metal ions in the liquid waste. However, at the same time, the catalytic retention effect of these ions can cause the observed decrease in $\mathrm{SO}_{2}$ and $\mathrm{NO}_{x}$ emissions compared to the slurry based on water [75].

Staron et al. [57] used waste soot during combustion in the composition of a coalwater slurry based on coal. The soot concentration was $2.5 \%, 7.5 \%$, or $10 \%$ [57]. Its use in the composition of a slurry is advisable for beneficial utilization and for improving the properties of the fuel (in particular, viscosity and stability). It was found that, if the particle size of the soot does not exceed $1 \mu \mathrm{m}$, then its addition has a positive effect on the stability of the slurry. Assessing a set of indicators (viscosity, density, stability, equivalent particle diameter), Staron et al. [57] concluded that the most preferable is a mixture with the composition " $40 \%$ of bituminous coal (low ash), $50 \%$ of water and $10 \%$ of soot". The coal for this fuel was finely dispersed (the equivalent diameter of $0.9 \mu \mathrm{m}$ ) and was crushed for $18 \mathrm{~h}$. The emissions during the combustion of a slurry of the preferred composition, as well as coal, were measured. The prepared fuel was injected by a nozzle into a combustion chamber (rotary kiln) heated to $800^{\circ} \mathrm{C}$. Staron et al. [57] found that the combustion of slurry instead of coal reduce $\mathrm{SO} 2$ emissions by three times and halve $\mathrm{NO}_{\mathrm{X}}$ emissions. High $\mathrm{CO}$ emissions are caused by incomplete combustion of particles due to insufficient residence time in the combustion chamber. According to Staron et al. [57], this problem can be solved on an industrial scale with a sufficiently large furnace size and at high temperatures.

\subsection{Summarizing the Results on Combustion of Low-Grade Liquid, Wet, and Slurry Fuels}

A review of the known research results in the field of combustion of low-grade liquid, slurry, and high-moisture fuels has shown that they can be quite promising for the energy industry. Potential benefits lie in the area of expanding the fuel base, reducing the cost of fuel preparation and improving several environmental performance indicators of a boiler. The main practical conclusions and projections for future research are given below:

(i) Compared to the incineration of dehydrated waste, low-grade slurry and liquid fuels can be burned even more efficiently, since they can be sprayed in the furnace as droplets, which provides better conditions for heat transfer and interaction with an oxidizer. In addition, some studies have confirmed that water and steam do not worsen, but, on the contrary, improve the characteristics of ignition, burnout, and contribute to multiple reductions of emissions (mainly sulfur and nitrogen oxides have been studied).

(ii) When burning low-grade liquid and slurry fuels, the following problems can potentially arise (Figure 3): long ignition delay, incomplete combustion, low combustion temperature, high emissions (including particulate matter, polycyclic aromatic hydrocarbons), low specific calorific value, low melting point of the mineral part (as a result-fast slagging), and high viscosity (as a result-difficult spraying).

(iii) A successful solution to these problems is possible due to conventional approaches (Figure 3), such as the use of auxiliary fuel during ignition starting up; boiler modification to ensure maximum burnout of droplets and particles; the use of modern equipment for cleaning flue gases. Special methods include oxy-fuel combustion, the use of an $\mathrm{O}_{2} / \mathrm{H}_{2} \mathrm{O}$ atmosphere, and the preparation of multi-component fuels, including the use of additives. The latter direction is of particular interest since it opens up wide opportunities for stabilizing important process parameters (combustion temperature, calorific value, etc.) and for obtaining synergistic effects, which, however, can be both positive and negative (for example, an increase in emissions).

(iv) One of the problems in the development of waste-to-energy technologies is the wide variety of properties of components, the chemical composition of their organic and inorganic parts. Therefore, it is quite difficult now to create a unified theory of combustion of mixed liquid, slurry fuels of different compositions, and, based on this theory, general standards for the design of boilers and other technological plants. Thus, it is very important to obtain new results on the combustion of unconventional fuel mixtures and individual 
components both in laboratory and in large-scale plants. Of particular interest is the detailing of the chemical reactions during the combustion of new fuels, as well as studies aimed at determining the optimal values of important parameters (both the fuel itself and external conditions).

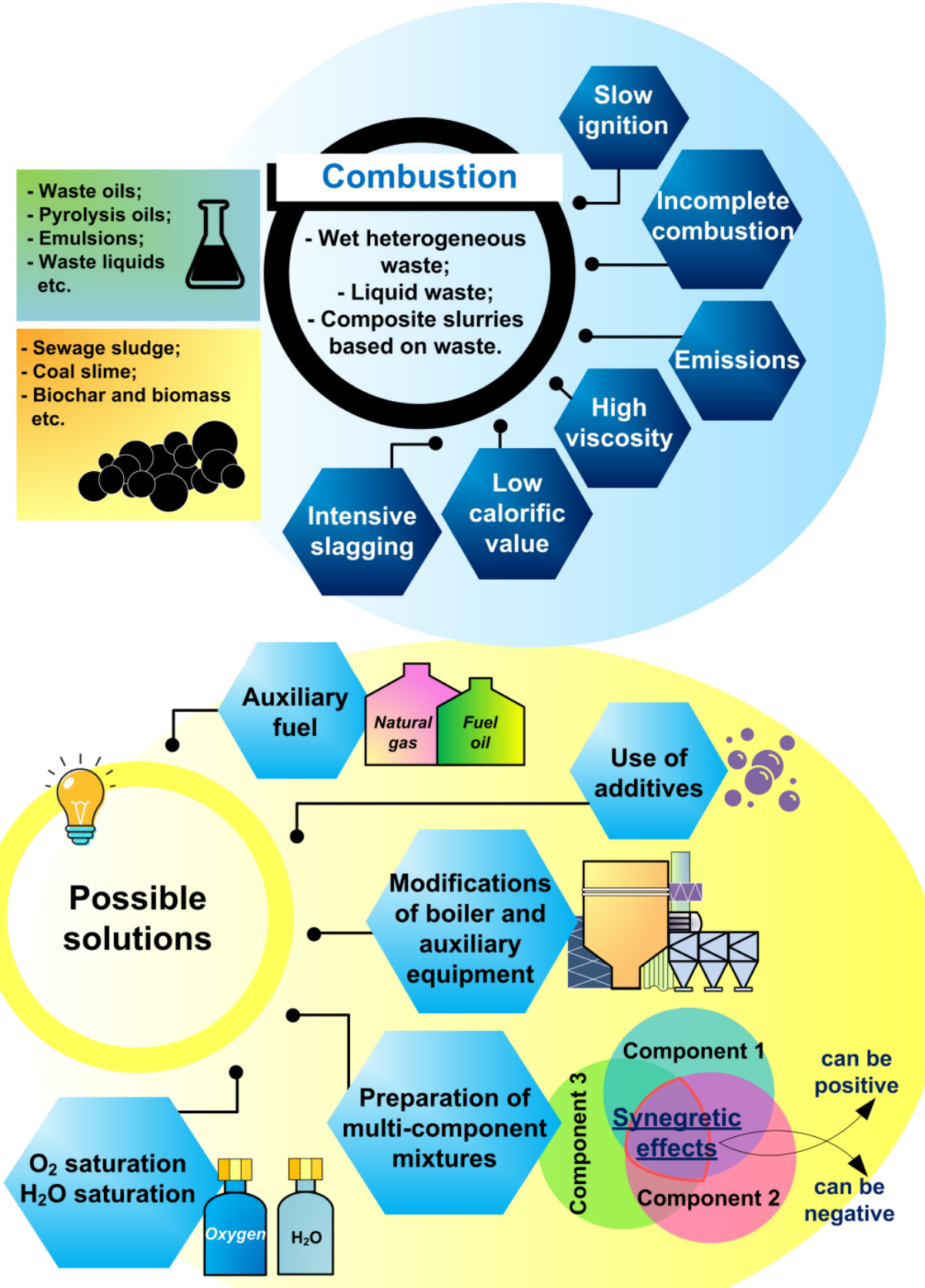

Figure 3. Features of combustion of low-grade high-moisture, slurry, and liquid fuels.

\section{Waste Conversion for Fuel Gas Production}

Gasification and pyrolysis are environmentally promising waste treatment technologies, as they produce less pollution in comparison with combustion, in particular, by $\mathrm{SO}_{x}$ and $\mathrm{NO}_{\mathrm{x}}$ emission [90]. Currently, a significant number of studies have been carried out on pyrolysis and gasification of conventional energy sources such as coal [91-93] and biomass [94-96]. However, the methods of thermal conversion of mixed waste-derived fuels to obtain fuel gas and other valuable pyrolysis products (char, oil) are less studied. 
The following sections of the article provide an overview of studies on pyrolysis and gasification of mixed and slurry fuels prepared based on wastes of different origins.

Figure 4 shows typical stages that occur during pyrolysis and gasification of fuels $[90,97]$. When a fuel particle is introduced into a heated medium, heating of the particle is observed, which intensifies moisture evaporation (drying stage). First, the external, unbound moisture evaporates, and then the internal one begins to evaporate in a quasi-stationary mode. After reaching the critical moisture content, the drying rate begins to decrease. After drying, the stage of primary pyrolysis follows, which is characterized by the release of volatile pyrolytic substances. Primary volatiles are formed as a result of the thermal rupture of the chemical bonds of individual fuel constituents. These include permanent gas particles (e.g., $\mathrm{CO}_{2}, \mathrm{CO}, \mathrm{H}_{2}$ ), ambient organic compounds (aliphatic and aromatic), and water. In addition to the listed substances, at this stage, a non-volatile carbon-riched solid residue (char) is formed. The resulting char contains a significant proportion of the minerals of the original fuel. In general, the primary pyrolysis stage is completed at temperatures of about $500{ }^{\circ} \mathrm{C}$. With a subsequent temperature increase, a part of the primary volatiles is involved in a variety of reactions of secondary pyrolysis $\left(500-700^{\circ} \mathrm{C}\right)$ and gasification $\left(700-1000{ }^{\circ} \mathrm{C}\right)$.

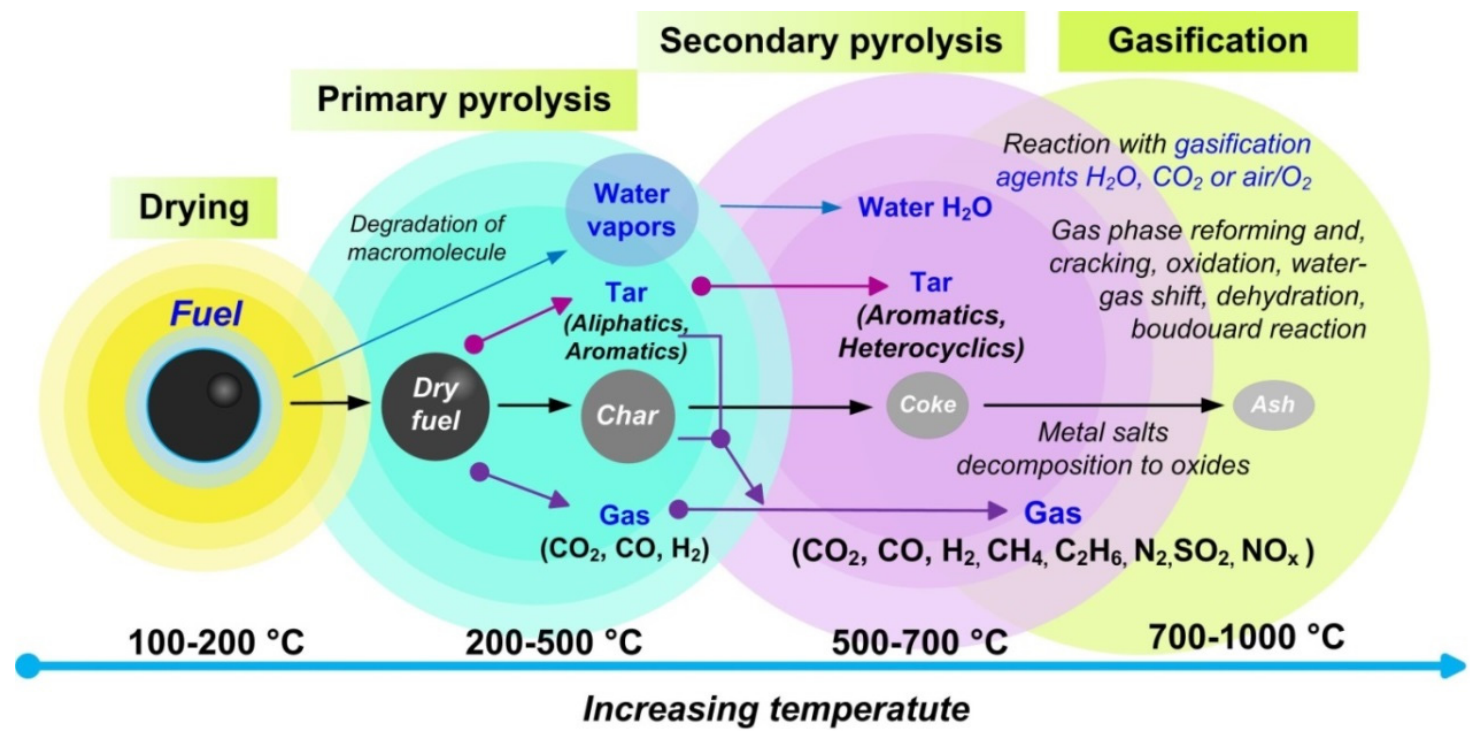

Figure 4. Scheme of thermal decomposition of a fuel particle indicating the main stages of pyrolysis and gasification.

However, there are no clear borders between primary and secondary pyrolysis [97] since secondary reactions of volatiles can occur simultaneously both in the pores of particles and in the volume of the gas. At high temperatures, sequential and parallel reactions proceed (heterogeneously or homogeneously), for example, cracking, reforming, dehydration, condensation, polymerization, oxidation, and gasification reactions. Under these conditions, char can be converted into gaseous particles during gasification reactions in an $\mathrm{H}_{2} \mathrm{O}$ atmosphere (which is especially important when using water-based slurries) and $\mathrm{CO}_{2}$ [97].

Table 3 presents data on studies of thermal decomposition of mixtures carried out in a laboratory and large scale. 
Table 3. Studies of pyrolysis and gasification of mixed fuels carried out via pilot, laboratory, and industrial installations.

\begin{tabular}{|c|c|c|c|c|c|}
\hline Fuel & Process & $\begin{array}{l}\text { Characteristics of the } \\
\text { Plant }\end{array}$ & Temperature & Key Result & Ref. \\
\hline $\begin{array}{c}\text { Coal-oil-water slurry } \\
\text { (COWS) } \\
\text { (coal } 45-55 \mathrm{wt} \% \text {, oil } \\
10-20 \mathrm{wt} \% ; \\
\text { water } 35 \mathrm{wt} \% \text { ) }\end{array}$ & Pyrolysis & $\begin{array}{l}\text { Laboratory tube furnace. } \\
\text { The carrier gas: } \mathrm{N}_{2} \text {, flow } \\
\text { rate } 0.8 \mathrm{~L} / \mathrm{min} \text {. } \\
\text { Experiment time: } 30 \mathrm{~min} \text {. } \\
\text { Particle size: } 75-100 \mu \mathrm{m} .\end{array}$ & $\begin{array}{l}800,900 \text { and } \\
1000^{\circ} \mathrm{C}\end{array}$ & $\begin{array}{l}\text { An increase in the temperature and the } \\
\text { proportion of water in the fuel contributed to an } \\
\text { increase in the gas yield up to } 2.8 \text { times, while } \\
\text { the char yield decreased to } 1.4 \text { times. The } \\
\text { addition of waste oil resulted in a decrease in } \\
\mathrm{CO} \text { and } \mathrm{CO}_{2} \text {, and an increase in } \mathrm{CH}_{4} \text { and } \mathrm{H}_{2} \text {. } \\
\text { Pyrolysis gas composition: } \mathrm{H}_{2}: 80-270 \mathrm{~mL} / \mathrm{g} \text {; } \\
\text { CO: } 35-110 \mathrm{~mL} / \mathrm{g} \text {; } \mathrm{CO}_{2}: 22-120 \mathrm{~mL} / \mathrm{g} ; \mathrm{CH}_{4} \text { : } \\
60-150 \mathrm{~mL} / \mathrm{g} \text {. }\end{array}$ & [62] \\
\hline $\begin{array}{c}\text { Coal wastewater } \\
\text { slurry (CWWS) } \\
\text { (coal 57.2-62 wt \%, } \\
\text { water } 42.8-38 \mathrm{wt} \% \text { ). }\end{array}$ & Gasification & $\begin{array}{l}\text { Industrial CWS gasifier to } \\
\text { produce syngas and } \\
\text { synthesize ammonia. } \\
\text { Syngas output } \\
515,116.8 \mathrm{~m}^{3} / \text { day. } \\
\text { Particle size: } 40 \mu \mathrm{m} .\end{array}$ & $1350-1400^{\circ} \mathrm{C}$ & $\begin{array}{c}\text { The syngas produced by the CWWS gasification } \\
\text { has a higher effective gas component }\left(\mathrm{CO}+\mathrm{H}_{2}\right) \\
\text { than the CWS. In addition, the use of a } \\
\text { waste-based slurry increased cold gas efficiency } \\
\text { by } 1.57 \% \text { and carbon conversion by } 0.45 \% \text { in } \\
\text { industrial processes. } \\
\text { Syngas composition: } \mathrm{H}_{2}: 30.5 \% ; \mathrm{CO}: 48.1 \% ; \mathrm{CO}_{2} \text { : } \\
16.3 \% ; \mathrm{CH}_{4}: 0.9 \% ; \mathrm{N}_{2}: 4.2 \% \text {. }\end{array}$ & [38] \\
\hline $\begin{array}{l}\text { Waste oil/coal slurry } \\
\text { (coal } 50 \mathrm{wt} \% \text {, mineral } \\
\text { waste oil } 50 \mathrm{wt} \% \text { ). }\end{array}$ & Pyrolysis & $\begin{array}{l}\text { Laboratory fluidized bed } \\
\text { reactor. } \\
\text { Feeding rate } 550 \mathrm{~g} / \mathrm{h} \text {. } \\
\text { Fuel mass } 3 \mathrm{~kg} \text {. }\end{array}$ & $625^{\circ} \mathrm{C}$ & $\begin{array}{l}\text { The quality of waste oil/coal slurry pyrolysis } \\
\text { products was higher compared to coal pyrolysis } \\
\text { products. During the slurry pyrolysis, the gas } \\
\text { yield increased from } 14.2 \% \text { to } 31.6 \% \text {, and the } \\
\text { liquid yield increased from } 17.4 \text { to } 29.1 \% \text { in } \\
\text { comparison with coal. At the same time, the } \\
\text { concentrations of } \mathrm{CH}_{4}, \mathrm{H}_{2}, \mathrm{C}_{2} \mathrm{H}_{4} \text {, and } \mathrm{C}_{2} \mathrm{H}_{6} \\
\text { increased by } 3.3,2.5,32 \text {, and } 10 \text { times, } \\
\text { respectively. } \\
\text { Pyrolysis gas composition: } \\
\mathrm{H}_{2}: 0.5 \mathrm{wt} \% ; \mathrm{CO}: 1.6 \mathrm{wt} \% ; \mathrm{CO}_{2}: 3.4 \mathrm{wt} \% ; \mathrm{CH}_{4}: \\
4.9 \mathrm{wt} \%, \mathrm{C}_{2} \mathrm{H}_{4}, 6.4 \mathrm{wt} \% ; \mathrm{C}_{2} \mathrm{H}_{6} 3 \mathrm{wt} \% \text {. }\end{array}$ & [39] \\
\hline $\begin{array}{l}\text { Lubricating Oil } \\
\text { Wastes (LOW) }\end{array}$ & Pyrolysis & $\begin{array}{l}\text { Laboratory pyrolysis unit. } \\
\text { Reactor is heated by an } \\
\text { electrical oven. Feeding } \\
\text { rate } 0.5 \mathrm{~g} / \mathrm{min} \text {. } \\
\text { Experiment time } 20 \mathrm{~min} .\end{array}$ & $600-700{ }^{\circ} \mathrm{C}$ & $\begin{array}{c}\text { Pyrolysis gas composition: } \\
\mathrm{H}_{2}: 0.01-0.02 \mathrm{~g} / \mathrm{kg} ; \mathrm{CO}: 0.03-0.04 \mathrm{~g} / \mathrm{kg} ; \mathrm{CO}_{2}: \\
0.04-0.08 \mathrm{~g} / \mathrm{kg} ; \mathrm{CH}_{4}: 0.35-0.93 \mathrm{~g} / \mathrm{kg} ; \mathrm{C}_{2} \mathrm{H}_{4}: \\
0.5-1 \mathrm{~g} / \mathrm{kg} ; \mathrm{C}_{2} \mathrm{H}_{6}: 0.25-0.47 \mathrm{~g} / \mathrm{kg} . \\
\text { Product Yield by Pyrolysis: } \\
\text { char: } 0.45-0.6 \mathrm{~g} / \mathrm{kg} ; \text { liquids: } 3.57-6.04 \mathrm{~g} / \mathrm{kg} ; \\
\text { gases: } 3.46-5.97 \mathrm{~g} / \mathrm{kg} ;\end{array}$ & [63] \\
\hline
\end{tabular}

Bamboo residual (BR) and waste lubricating oil (WLO)
Pyrolysis catalytic beds HZSM-5 and $\mathrm{MgO}$. Fast pyrolysis: heating rate $2000{ }^{\circ} \mathrm{C} / \mathrm{s}$ Particle size: $0.15 \mu \mathrm{m}$.
$500-700{ }^{\circ} \mathrm{C} \quad$ The temperature of $600^{\circ} \mathrm{C}$ was optimal due to the relatively high yields of furans and phenols.

When ethanol was used in the slurry, an increase was recorded in syngas heating value (by 9\%), syngas flow rate (by $38 \%$ ), syngas production

Coal water ethanol slurry (CWES) (coal $57 \mathrm{wt} \%$, water

$36 \mathrm{wt} \%$, ethanol $7 \mathrm{wt} \%)$.

\section{Gasification gasifier. \\ Feeding rate at 20 bar: $96.15 \mathrm{~kg} / \mathrm{h}$.}

Pilot-scale entrained flow
$1100{ }^{\circ} \mathrm{C}$ per $1 \mathrm{~kg}$ of slurry (by 25\%), cold gas efficiency (by $39 \%$ ) and carbon conversion efficiency (by 15\%).

Syngas composition: $\mathrm{H}_{2}: 34.50 \mathrm{vol} \%$; CO: $29.69 \mathrm{vol} \% ; \mathrm{CO}_{2}: 35.33 \mathrm{vol} \%$; $\mathrm{CH}_{4}: 0.47 \mathrm{vol} \%$.

Addition of $\mathrm{CaO}$ and $\mathrm{Fe}$ increased the char yield (in 1.2 times) and $\mathrm{H}_{2}$ contents (in 2.5 times), and decreased $\mathrm{CO}_{2}$ content in the non-condensable gas.

Pyrolysis gas composition:

Textile dyeing sludge (DS) with $20-30 \mathrm{wt} \%$ additives $(\mathrm{CaO}$,

Ca-bentonite, Kaolin and $\mathrm{Fe}$ )
Two-mode microwave device with $2.45 \mathrm{GHz}$

Pyrolysis frequency and the maximum power of $3 \mathrm{~kW}$. Particle size: $<1 \mathrm{~mm}$.
$450-750{ }^{\circ} \mathrm{C}$
Without additives: $\mathrm{H}_{2}$ : $20-33 \mathrm{vol} \%$; $\mathrm{CO}$

$12-15 \mathrm{vol} \% ; \mathrm{CO}_{2}$ : $0-65 \mathrm{vol} \% ; \mathrm{CH}_{4}: 0-5 \mathrm{vol} \%$. With additives: $\mathrm{H}_{2}$ : $12-62 \mathrm{vol} \%$; $\mathrm{CO}: 15-20 \mathrm{vol} \%$; $\mathrm{CO}_{2}: 45-65 \mathrm{vol} \% ; \mathrm{CH}_{4}: 4-15 \mathrm{vol} \%$. Product Yield by Pyrolysis:

char: $60-80 \mathrm{wt} \%$; liquids: $10-14 \mathrm{wt} \%$; gases: 
Table 3. Cont.

\begin{tabular}{|c|c|c|c|c|c|}
\hline Fuel & Process & $\begin{array}{c}\text { Characteristics of the } \\
\text { Plant }\end{array}$ & Temperature & Key Result & Ref. \\
\hline $\begin{array}{l}\text { Corn starch, clover } \\
\text { grass, and corn silage } \\
\text { in supercritical water }\end{array}$ & $\begin{array}{l}\text { Gasification } \\
\text { in } \\
\text { supercritical } \\
\text { water }\end{array}$ & Continuous flow reactor & $500-700{ }^{\circ} \mathrm{C}$ & $\begin{array}{l}\text { Gasification of biomass in supercritical water is } \\
\text { highly temperature-dependent. Almost } \\
\text { complete conversion of the feed can be achieved } \\
\text { at } 700{ }^{\circ} \mathrm{C} \text {. As the temperature rises, the } \mathrm{H}_{2} \text { yield } \\
\text { increases, but the } \mathrm{CO} \text { concentration decreases. } \\
\text { Syngas composition: } \\
\mathrm{H}_{2}: 29.7-34.4 \mathrm{vol} \% \text {; CO: } 0.62-2.8 \mathrm{vol} \% ; \mathrm{CO}_{2} \text { : } \\
39.7-43.9 \mathrm{vol} \% ; \mathrm{CH}_{4}: 15-20.5 \mathrm{vol} \% ; \mathrm{C}_{2} \mathrm{H}_{2} \text { : } \\
2.6-4.8 \text { vol } \% \text {. }\end{array}$ & \\
\hline $\begin{array}{l}\text { Water-semicoke } \\
\text { slurry (semicoke } \\
\text { 10-30 wt \%). }\end{array}$ & $\begin{array}{l}\text { Gasification } \\
\text { in } \\
\text { supercritical } \\
\text { water }\end{array}$ & $\begin{array}{l}\text { Supercritical water } \\
\text { fluidized bed } \\
\text { reactor system. } \\
\text { Pressure } 23 \mathrm{MPa} \text {. } \\
\text { Water flow rate } 40 \mathrm{~g} / \mathrm{min} \text {, } \\
\text { slurry flow rate } \\
20 \mathrm{~g} / \mathrm{min} / \\
\text { Particle size: }<100 \mu \mathrm{m}\end{array}$ & $540-660^{\circ} \mathrm{C}$ & $\begin{array}{l}\text { The temperature of } 600{ }^{\circ} \mathrm{C} \text { is the most preferred } \\
\text { to provide full gasification of the fixed carbon is } \\
\text { realized. The use of } \mathrm{K}_{2} \mathrm{CO}_{3} \text { as a catalyst made it } \\
\text { possible to increase the hydrogen yield by } 92 \% \text {. } \\
\text { Syngas composition: } \\
\mathrm{H}_{2} \text { : } 50-55 \mathrm{vol} \% \text {; } \mathrm{CO}: 2-3 \mathrm{vol} \% ; \mathrm{CO}_{2}: 35-38 \mathrm{vol} \% \text {; } \\
\qquad \mathrm{CH}_{4}: 10-12 \mathrm{vol} \% \text {. }\end{array}$ & {$[54]$} \\
\hline
\end{tabular}

Based on the literature analysis, we can identify the main research directions on the pyrolysis and gasification of mixed waste-derived fuels: (i) pyrolysis and gasification of coal-water slurries with industrial waste additives; (ii) the effect of external conditions on the characteristics of the end products of pyrolysis and gasification; (iii) the use of specialized additives and catalysts to increase the pyrolysis and gasification efficiency.

\subsection{Pyrolysis and Gasification of Coal-Water Slurries with Industrial Waste Additives}

Increasing the efficiency of pyrolysis and gasification due to the use of oil waste in the composition of CWS and varying the ratio of components is relevant to research. For example, the characteristics of gaseous and solid pyrolysis products of slurry fuels were considered by Wan et al. [62]. The conventional CWS and the slurry with an admixture of waste lubricating oil were studied. The used lubricating oil was obtained from a local vehicle maintenance plant (Hubei, China). The shares of coal (55-65 wt $\%)$, water (35-45 wt $\%$ ), and waste lubricating oil (10-20 wt\%) varied. The experiments were carried out using a tube electric furnace at a temperature of $800-1000{ }^{\circ} \mathrm{C}$. It was found that an increase in the proportion of water in slurries promoted an increase in the gas yield. At fast heating, water reacted with volatiles or coal, contributing to the formation of additional gaseous products. As the water content in the CWS increased, the concentrations of $\mathrm{CO}_{2}$ and $\mathrm{H}_{2}$ increased, while $\mathrm{CO}$ and $\mathrm{CH}_{4}$, on the contrary, decreased. The water promoted the reforming of the $\mathrm{CH}_{4}$ and water gas shift reaction, which intensified with an increase in the water proportion. Similar tendencies were also observed by Ding et al. [93].

The addition of waste oil to the CWS did not have a sufficient effect on the amount of pyrolysis gas. However, it was found that the ratio of the main gas components $\left(\mathrm{CO}_{2}\right.$, $\mathrm{CO}, \mathrm{CH}_{4}, \mathrm{H}_{2}$ ) changed when using oil. The concentrations of hydrogen and methane increased during pyrolysis of coal-oil-water slurry, while the emission of carbon oxides decreased. The decomposition of aliphatic compounds during pyrolysis of waste lubricating oil promoted the release of $\mathrm{CH}_{4}$, while the formation of $\mathrm{H}_{2}$ was the direct decomposition and re-condensation reaction. The study of the characteristics of the char obtained during pyrolysis showed that higher pyrolysis temperatures led to a decrease in the reactivity of char (the delay of its ignition increased). Similar trends were also noticed with an increase in the proportion of water and used turbine oil [62].

Four types of wastewater were used for the preparation of coal wastewater slurry and its gasification [38]. Li et al. [38] examined wastewater generated from CWS gasification: washing wastewater (GWW), sulfur wastewater (SW), and carbonized wastewater (CW), and also industrial wastewater (IW) from an external source. The experiments were carried out in a commercial gasification plant for coal water slurry to produce syngas 
and synthesize ammonia. Li et al. [38] found that the use of CWWS instead of CWS did not lead to disruptions in the operating modes of the gasifier. The total gas yield was $515,116.8 \mathrm{~m}^{3} /$ day. This made it possible to conclude that the gasification proceeded stably regardless of the fuel type (CWS or CWWS). The comparison of the syngas composition showed that the average share of the effective gas component $\left(\mathrm{CO}+\mathrm{H}_{2}\right)$ during CWWS gasification was higher and amounted to $78.3 \%$, while, for CWS, this parameter was $77.2 \%$. In addition, $\mathrm{Li}$ et al. [38] calculated that the carbon conversion rate and cold gas efficiency during gasification of CMWS are $0.45 \%$ and $1.57 \%$ higher than that of CWS, respectively. This result [38] is because CWWS contains more organic matter, the decomposition of which produces gas of better quality. Alkali and alkaline earth metals, as well as organic alkalis in wastewater, influenced the char structure in the direction of increasing the reactivity and decreasing the activation energy during coal gasification [38].

Lázaro et al. [39] studied the synergistic effects arising from the co-pyrolysis of coal and waste mineral oil (MWO). Sub-bituminous coal with high volatile content and MWO obtained from a local company were used in the experiments. The components were mixed in a 50/50 ratio. The pyrolysis of the mixture was carried out in a laboratory fluidized bed reactor with the fuel feed rate of $550 \mathrm{~g} / \mathrm{h}$. The gas was analyzed using gas chromatography, the liquids were analyzed by GC/MS. Lázaro et al. [39] defined that the pyrolysis of the mixture increased the yield of gas (2.2 times) and liquid (1.7 times) pyrolysis products, while the amount of char decreased (1.7 times) in comparison with coal. At the same time, the quality of the products of coal and oil co-pyrolysis increased. Lázaro et al. [39] recorded a significant increase in the concentrations of methane, ethylene, and propylene. For MWO/coal slurry, the concentrations of $\mathrm{CH}_{4}, \mathrm{C}_{2} \mathrm{H}_{6}$, and $\mathrm{C}_{2} \mathrm{H}_{4}$ were $4.9 \mathrm{wt} \%, 3 \mathrm{wt} \%$ and $6.4 \mathrm{wt} \%$, respectively. For coal, the concentrations of these gases were $1.2 \mathrm{wt} \%, 0.3 \mathrm{wt} \%$ and $0.2 \mathrm{wt} \%$. The obtained result was explained by gas-phase reactions between volatile substances of coal and vapors of MWO. In addition, Lázaro et al. [39] estimated the distribution of heavy metals in liquid and solid pyrolysis products and found that the concentrations of $\mathrm{Pb}$ and $\mathrm{Ni}$ in the pyrolysis liquid were lower than in the original waste oil. In the composition char, the concentrations of these metals, on the contrary, had increased values. This means that the char formed during the joint pyrolysis of liquid waste and coal was a sorbent for heavy metals, preventing them from entering the gas and liquid phases [39].

Bae et al. [48] found a positive effect of ethanol ( $7 \mathrm{wt} \%)$ on the efficiency of coal-water slurry gasification. The research was carried out using a pilot-scale entrained flow gasifier (operating temperature of $1100^{\circ} \mathrm{C}$ ). Compared to conventional CWS, the gasification of slurry with ethanol exhibited higher cold gas efficiency $(42.6 \%)$ and carbon conversion efficiency $(70.22 \%)$. With the use of ethanol, syngas production per $1 \mathrm{~kg}$ of slurry increased from $0.61 \mathrm{~m}^{3}$ to $0.76 \mathrm{~m}^{3}$. The syngas heating value increased by $10 \%$. The composition of syngas during CWS gasification was the following: $\mathrm{H}_{2}=29.80 \mathrm{vol} \%, \mathrm{CO}=28.82 \mathrm{vol} \%$, $\mathrm{CH}_{4}=0.56 \mathrm{vol} \%$, and $\mathrm{CO}_{2}=40.83 \mathrm{vol} \%$. When ethanol was added, the syngas contained $34.50 \mathrm{vol} \% \mathrm{H}_{2}, 29.69 \mathrm{vol} \% \mathrm{CO}, 0.47 \mathrm{vol} \% \mathrm{CH}_{4}$, and $35.33 \mathrm{vol} \% \mathrm{CO}_{2}$. It was shown [48] that the gasification efficiency is directly related to the carbon content in the fuel. The use of ethanol made it possible to increase the share of the coal up to $57 \mathrm{wt} \%$ while maintaining the slurry viscosity at $2000 \mathrm{cP}$. Thus, the increased carbon content in coal-water-ethanol slurry improved the quality of syngas [48].

\subsection{Influence of External Conditions on the Characteristics of the Pyrolysis and Gasification Products}

Many studies confirm that temperature is the most important factor influencing the quantitative and qualitative characteristics of pyrolysis products. D'Jesús et al. [67] studied the gasification of corn and clover grass in supercritical water. A continuous flow reactor was used. The temperature varied from 500 to $700^{\circ} \mathrm{C}$. Under supercritical water gasification conditions, biomass reacts with water according to the reaction $\mathrm{C}_{6} \mathrm{H}_{12} \mathrm{O}_{6}+6 \mathrm{H}_{2} \mathrm{O} \rightarrow 6 \mathrm{CO}_{2}$ $+12 \mathrm{H}_{2}$. D'Jesús et al. [67] found that an increase in temperature from 500 to $700{ }^{\circ} \mathrm{C}$ 
increased the gasification efficiency indicator up to 2.24 times. The gas yield increased by $20 \%$. The temperature rise also influenced the gas composition. At higher temperatures, $\mathrm{CO}_{2}$ content decreased, while the methane concentration, on the contrary, increased to $20 \mathrm{vol} \%$ (compared to $10 \mathrm{vol} \%$ at $500{ }^{\circ} \mathrm{C}$ ). Additional methane could be generated both from $\mathrm{CO} / \mathrm{CO}_{2}$, and directly from the reacting biomass [67]. $\mathrm{H}_{2}$ concentrations also increased with increasing temperature. Hydrogen is released from both water and biomass. However, $\mathrm{CO}$ formation was inhibited due to the water-gas shift reaction $\left(\mathrm{CO}+\mathrm{H}_{2} \mathrm{O} \rightarrow \mathrm{CO}_{2}+\mathrm{H}_{2}\right)$ dominating at high temperatures. Thus, at $500{ }^{\circ} \mathrm{C}$, the $\mathrm{CO}$ concentration was $15 \mathrm{vol} \%$, and at $700{ }^{\circ} \mathrm{C}$, it was less than $1 \mathrm{vol} \%$. Sato et al. [98] investigated the kinetics of a water-gas shift reaction under non-catalytic conditions in supercritical water and found that the $\mathrm{CO}$ conversion increased by more than 2.5 times with an increase in temperature by $60^{\circ} \mathrm{C}$.

The study [54] is devoted to finding an effective way to use semicoke powder. This component is a finely dispersed by-product of the coal chemical industry and accounts for $10 \%$ of the total amount of semicoke. Direct combustion of semicoke powders in a boiler is complicated by the low content of volatiles and high ignition temperatures. Cheng et al. [54] suggested using semicoke powders in supercritical water gasification technologies. The semi-coke was ground to a size less than $100 \mu \mathrm{m}$, and $0.1 \mathrm{wt} \%$ xanthan gum was used as a stabilizer. Deionized water and alkaline catalysts were then added to the mixture to obtain a uniform and stable water-semicoke slurry. The experiments were carried out in a supercritical water fluidized bed reactor system. The temperature range was $540-660{ }^{\circ} \mathrm{C}$. The pressure in the system was $23 \mathrm{MPa}$. Cheng et al. [54] showed that, with an increase in temperature from $540{ }^{\circ} \mathrm{C}$ to $660{ }^{\circ} \mathrm{C}$, the carbon gasification efficiency and hydrogen yield increase from $27.83 \%$ to $95.26 \%$ and from $17.53 \mathrm{~mol} / \mathrm{kg}$ to $85.90 \mathrm{~mol} / \mathrm{kg}$, respectively. The high temperature facilitated the steam reforming reaction. With an increase in temperature, the proportion of carbon monoxide increased from $1.84 \%$ to $2.75 \%$, and the proportion of carbon dioxide decreased from $37.01 \%$ to $30.01 \%$, since the higher temperature promoted the reverse reaction of water gas conversion $\left(\mathrm{CO}+\mathrm{H}_{2} \mathrm{O} \rightarrow \mathrm{CO}_{2}+\mathrm{H}_{2}\right)$. As the concentration of semicoke powders increased from 10 to $30 \mathrm{wt} \%$, the hydrogen concentration decreased from $55.06 \%$ to $50.26 \%$, and the methane concentration increased from $8.14 \%$ to $12.57 \%$. The authors assumed that there is a competition of the hydrogen element between $\mathrm{H}_{2}$ and $\mathrm{CH}_{4}$. It is mainly because the lower concentration of water inhibits the water gas shift reaction and the methane steam reforming reaction [54].

The pyrolysis of lubricating oil wastes was studied by Moliner et al. [63]. Gases were analyzed by gas chromatography (GC), liquids-by gas chromatography/mass spectrometry (GC/MS). Moliner et al. [63] found that, with the temperature rise, the gas yield increased from 3.46 to $5.97 \mathrm{~g} / \mathrm{kg}$, and the liquid yield decreased from 6.04 to $3.57 \mathrm{~g} / \mathrm{kg}$; the yield of the solid part varied in a small range from 0.45 to $0.6 \mathrm{~g} / \mathrm{kg}$. The increase in the gas yield with an increase in temperature from 600 to $700{ }^{\circ} \mathrm{C}$ is mainly associated with an increase in the concentrations of methane, ethylene, and propylene. A similar effect was also found when using waste lubricating oil as an additive to the coal-water slurry [62]. With an increase in temperature from 800 to $1000{ }^{\circ} \mathrm{C}$, the gas volume increased up to 2.8 times due to the intensification of coal decomposition reactions. The proportion of the solid residue decreased to 1.5 times [62]. Moliner et al. [63] concluded that the pyrolysis conditions should be determined based on the purpose of the pyrolysis products. In the petrochemical industry, which involves the use of petrochemical feedstocks, a temperature range of 650 to $700{ }^{\circ} \mathrm{C}$ and a pressure of $0.1 \mathrm{MPa}$ should be selected. Under these conditions, most of the hydrogen contained in the waste oil is converted to olefins $\mathrm{C}_{2}-\mathrm{C}_{4}$ olefins and BTX (benzene, toluene, and xylene). For the related industries producing gas fuel and liquid, a temperature of $700{ }^{\circ} \mathrm{C}$ and a pressure of $0.5-1 \mathrm{MPa}$ are preferred. In this case, a higher proportion of hydrogen is converted to $C_{1}-C_{3}$ alkanes and BTX (preferred as fuel).

In addition to temperature, the oxidizing medium of pyrolysis/gasification has a significant effect on the characteristics of these processes. Tamošiūnas et al. [64] used water steam as a gasifying agent during gasification waste cooking oil (WCO) in a plasma chemical reactor. The effect of the gasifying agent-to-feedstock ratio on the gasification 
efficiency of waste cooking oil has been studied. As the Steam/WCO ratio increased from 1.31 to 2.33 , the $\mathrm{H}_{2}$ concentration increased from $40.58 \mathrm{vol} \%$ to $47.9 \mathrm{vol} \%$. This is due to steam reforming, water-gas shift, and cracking reactions. $\mathrm{CO}$ concentrations practically did not change and amounted to $22-23.5 \mathrm{vol} \%$. An increase in the Steam/WCO ratio from 1.31 to 2.33 resulted in a slight decrease in the methane content from $9.44 \mathrm{vol} \%$ to $7.83 \mathrm{vol} \%$. This will be explained by reverse methanation and hydrogenation reactions, whereby methane and water forms hydrogen, carbon monoxide, or carbon dioxide. The $\mathrm{CO}_{2}$ concentration increased from $5.83 \mathrm{vol} \%$ to $7.74 \mathrm{vol} \%$. The lower calorific value of the generator gas with varying the Steam/WCO ratio changed from $12.5 \mathrm{MJ} / \mathrm{Nm}^{3}$ to $13.2 \mathrm{MJ} / \mathrm{Nm}^{3}$, which indicates the generation of good quality gas in a water-steam medium.

Gasification of coal-oil emulsion в lab-scale gasifier at temperatures between 800 and $925^{\circ} \mathrm{C}$ was studied by Svoboda et al. [99]. Oxygen-steam and oxygen- $\mathrm{CO}_{2}$ mixtures were chosen as the gasifying atmosphere. It has been established that, during the gasification of coal-oil emulsion of a water steam medium, lower heating values of the produced gas were two times higher $\left(18-20 \mathrm{MJ} / \mathrm{m}^{3}\right)$ than the calorific value of the gas $\left(18-20 \mathrm{MJ} / \mathrm{m}^{3}\right)$ obtained during gasification in oxygen- $\mathrm{CO}_{2}$ mixtures, due to high content of diluting $\mathrm{CO}_{2}$. The amount of $\mathrm{CO}_{2}$ in the composition of the gas decreased by $43 \%$ in the water steam medium. The concentrations of $\mathrm{H}_{2}, \mathrm{CH}_{4}$, and $\mathrm{CO}$ increased by $20 \%, 30 \%$, and $15 \%$, respectively [99]. Gasification of coal-oil slurry, bio-oil, and coal-water-slurry in entrained-flow gasifier was studied by Feng et al. [100]. The $\mathrm{N}_{2}$-water steam mixture was chosen as the gasifying medium. The temperature in the reactor was varied in the range of $1200-1400{ }^{\circ} \mathrm{C}$. An analysis of the composition of the gas obtained during the gasification of three fuels showed that the coal-water-slurry ( $40 \mathrm{wt} \%$ coal, $60 \mathrm{wt} \%$ water) was characterized by the maximum yield of $\mathrm{H}_{2}(59.84 \mathrm{vol} \%)$ and the minimum share of $\mathrm{CO}_{2}(21.19 \mathrm{vol} \%)$. The largest concentration of methane was recorded during the gasification of coal-oil slurry (20 wt $\%$ coal, $80 \mathrm{wt} \%$ bio-oil). The maximum concentration of CO $(18.97 \mathrm{vol} \%)$ in the gas was recorded during experiments with bio-oil [100].

Factors such as residence time, heating rate, and pressure of the pyrolysis and gasification also affect the composition of pyrolysis and gasification products. D'Jesús et al [67] found that increasing the residence time to a certain value (up to $10 \mathrm{~min}$ in this work) increases gas production during biomass gasification in supercritical water. A further increase in the residence time did not significantly affect the composition of the gas. The content of hydrogen and carbon monoxide increased with shorter residence times, while the content of methane and ethane in the gas phase decreased [67]. Liu and Yuan [101] studied the catalytic pyrolysis of waste cooking oil. They found that the yield of hydrogen decreased from 42 to $31 \mathrm{vol} \%$ when residence time was $4 \mathrm{~h}$, which indicated a decrease in catalyst activity over time. At the same time, the concentration of methane increased from 10 to $19 \mathrm{vol} \%$ [93].

Kruse et al. [102] studied gasification of a model compound for lignin in biomass and for aromatic compounds in wastewaters-pyrocatechol in a in supercritical water. It is shown that, with an increase in pressure from 0 to $400 \mathrm{bar}$, the relative yield of hydrogen decreased, while the yield of methane increased up to 2 times. The concentrations of other gases changed insignificantly. In the general case, theoretical and experimental results [102] show that an increase in temperature and a decrease of pressure leads to an increase of hydrogen formation as well as a decrease in the methane yield. At $700{ }^{\circ} \mathrm{C}$, the hydrogen yield increases with reaction time from 0.25 to $2 \mathrm{~min}$. This may be due to the thermal decomposition of methane, which is a rather slow reaction [102]. The heating rate of fuel samples was discussed in [103]. The heating rate was varied in the range of $100-500{ }^{\circ} \mathrm{C} / \mathrm{min}$. It was found that, when the heating rate was increased from $200^{\circ} \mathrm{C} / \mathrm{min}$ to $300{ }^{\circ} \mathrm{C} / \mathrm{min}$, the yield of non-condensable gas increased up to 2 times, while the yield of tar decreased. It is known [104] that high temperatures and long residence times favor the formation of non-condensable gaseous products due to secondary reactions within the particles [104]. These secondary reactions lead to additional decomposition of the tar and the formation 
of gas. However, at higher heating rates, the gas production decreased because the rapid release of tar broke through the heat and mass transfer limits [102].

\subsection{Specialized Additives and Catalysts to Increase the Efficiency of Pyrolysis and Gasification of Waste}

The studies $[44,46,50,52,63]$ have shown that alkaline catalysts play an important role in the pyrolysis and gasification of fuels. Microwave pyrolysis of textile dyeing sludge (DS) was analyzed by Zhang et al. [56]. The DS was obtained from a wastewater treatment plant for dying and printing industries (Jiangsu province, southeastern part of China). Zhang et al. studied the effect of additives ( $\mathrm{CaO}, \mathrm{Ca}$-bentonite, Kaolin, and $\mathrm{Fe}$ ) and oven temperature on the yield of pyrolysis products and their properties. It was found that the yield of non-condensable gases increased from $3.2 \mathrm{wt} \%$ to $14 \mathrm{wt} \%$ as the temperature varied from 450 to $750{ }^{\circ} \mathrm{C}$. However, the condensate and oil yields increased with temperature changes from 450 to $650{ }^{\circ} \mathrm{C}$ and reached their maximum values $(12.9 \mathrm{wt} \%$ and $0.8 \mathrm{wt} \%$, respectively) at $650{ }^{\circ} \mathrm{C}$. A further increase in temperature to $750{ }^{\circ} \mathrm{C}$ was accompanied by a decrease in the proportion of liquid pyrolysis products. When the temperature was raised to $750{ }^{\circ} \mathrm{C}$, the oil underwent reforming and cracking inside the reaction zone, which reduced the pyrolysis gas yield. Studies $[105,106]$ also confirm that the range of $450-650{ }^{\circ} \mathrm{C}$ is most favorable for pyrolysis oil production, depending on the properties of raw materials, type of reactor, and operating conditions. Zhang et al. [56] also found that, depending on the additive used, the composition of the gas can be significantly changed. $\mathrm{CaO}$ was found to be the most preferred additive in the amount of $30 \mathrm{wt} \%$. The use of $\mathrm{CaO}$ increased the $\mathrm{H}_{2}$ concentration from $25 \mathrm{vol} \%$ (without additives) to $65 \mathrm{vol} \%$. At the same time, $\mathrm{CO}_{2}$ emissions decreased to $0.3 \mathrm{vol} \%$ (without additive, $\mathrm{CO}_{2}=55 \mathrm{vol} \%$ ). The addition of $\mathrm{Fe}$ to the dyeing sludge also had a beneficial effect on the concentrations of $\mathrm{H}_{2}$ and $\mathrm{CO}_{2}$ but to a much lesser extent $\left(\mathrm{H}_{2}\right.$ concentrations increased to $32 \%, \mathrm{CO}_{2}$ decreased by $\left.48 \mathrm{vol} \%\right)$. $\mathrm{CaO}$ and Fe can facilitate the reactions of dehydrogenation and dehydration [107]. When using $\mathrm{CaO}$ and $\mathrm{Fe}$, the concentrations of $\mathrm{CO}$ and $\mathrm{CH}_{4}$ increased (from 1.75 to 3 times), which could be associated with cracking reactions, water gas, reforming, and reverse Boudouard reactions. The addition of kaolin to the dyeing sludge also contributed to higher $\mathrm{CO}$ and $\mathrm{CH}_{4}$ yields. In this case, kaolin reduced the yield of solid residue and increased the yield of condensate. In contrast, the addition of $20 \mathrm{wt} \%$ Ca-bentonite had a negative impact on the gas quality. $\mathrm{CO}_{2}$ concentration increased and $\mathrm{H}_{2}$ concentration decreased compared to dyeing sludge without additives [56].

Fast catalytic co-pyrolysis of bamboo residual and waste lubricating oil (WLO) was studied by Wang et al. [46]. A dual catalytic bed system (MgO and HZSM-5) in CDS analytical Pyroprobe 5200 pyrolyzer was used. The composition of the pyrolysis products was analyzed using the GC/MS system. Wang et al. [46] considered the influence of the pyrolysis temperature, the types of catalysts and their mass ratio, and the WLO content on the distribution of pyrolysis products and the selectivity of aromatic hydrocarbons. Experiments have shown that $600^{\circ} \mathrm{C}$ is the optimum temperature in terms of the yield of condensable organic products, furans, and phenols. When comparing the two catalysts, $\mathrm{MgO}$ was found to be more preferable in terms of maximizing the yield of light phenols. $\mathrm{MgO}$ also reduced acidity through ketonization and aldol condensation reactions. The minimum yield of acids $(2.12 \%)$ and the maximum yield of ketones $(28.81 \%)$ were obtained. An increase in the share of WLO intensified the yield of hydrocarbons (i.e., olefins, alkanes), the maximum yield $(70.31 \%)$ of which was achieved with an oil percentage of $60 \%$. Waste oil was the main source of hydrogen, which aided the production of aromatic hydrocarbons [46].

Catalytic pyrolysis of waste cooking oil was investigated by Liu et al. [101]. The effect of nickel-cobalt catalyst and reaction temperature on hydrogen production was studied. The maximum volume concentration of hydrogen $(42 \mathrm{vol} \%)$ at a temperature of $750{ }^{\circ} \mathrm{C}$ was registered using a catalyst containing $20 \mathrm{wt} \% \mathrm{Ni}$ and $30 \mathrm{wt} \% \mathrm{Co}$. It was found that the maximum hydrogen concentration of $43.5 \mathrm{vol} \%$ was reached at $800^{\circ} \mathrm{C}$. A further increase in 
temperature caused sintering of the catalyst and subsequent loss of activity. The study also concluded that single metal catalysts exhibit a higher deactivation rate and lower catalytic effect than bimetallic catalysts [101].

Cheng et al. [54] found that the addition of catalysts significantly improves the efficiency of water-semicoke slurry gasification and hydrogen yield. Compared to $4.66 \mathrm{~mol} / \mathrm{kg}$ without catalyst, the hydrogen yield increased to $55.78,54.43,51.06$, and $53.79 \mathrm{~mol} / \mathrm{kg}$ after the addition of $\mathrm{K}_{2} \mathrm{CO}_{3}, \mathrm{KOH}, \mathrm{Na}_{2} \mathrm{CO}_{3}$, and $\mathrm{NaOH}$, respectively. With an increase in the proportion of $\mathrm{K}_{2} \mathrm{CO}_{3}(0-5 \%)$, the number of porous structures on the surface of the char increased. Mesoporous structures increased the contact area between char particles and water molecules, which increased the efficiency of gasification. The increase in the amount of catalyst promoted the steam reforming reaction $\left(\mathrm{C}+\mathrm{H}_{2} \mathrm{O} \rightarrow \mathrm{CO}+\mathrm{H}_{2}\right)$.

The advantages of potassium-containing catalysts were also discussed in [102,108]. Kruse et al. [102] showed that, with an increase in $\mathrm{KOH}$ concentration from 0 to $5 \mathrm{wt} \%$, the hydrogen content in the gaseous pyrolysis product of pyrocatechol (model compound for lignin in biomass and for aromatic compounds in wastewaters) increases from $16 \mathrm{vol} \%$ to $48 \mathrm{vol} \%$. Sinag et al. [108] explained the emerging catalytic effect when using potassiumcontaining catalysts $\left(\mathrm{KOH}, \mathrm{K}_{2} \mathrm{CO}_{3}\right)$ by the enhancement of the water gas shift reaction due to the intermediate formation of the salt ( $\mathrm{HCOO}-\mathrm{K})$. The formation of the formate salt in the presence of $\mathrm{K}_{2} \mathrm{CO}_{3}$ can be shown by the reactions: $\mathrm{K}_{2} \mathrm{CO}_{3}+\mathrm{H}_{2} \mathrm{O} \rightarrow \mathrm{KHCO}_{3}+\mathrm{KOH}$, $\mathrm{KOH}+\mathrm{CO} \rightarrow \mathrm{HCOOK}, \mathrm{HCOOK}+\mathrm{H}_{2} \mathrm{O} \rightarrow \mathrm{KHCO}_{3}+\mathrm{H}_{2}$. As a result, $\mathrm{CO}$ reacts with $\mathrm{KOH}$ to form $\mathrm{HCOOK}$. Potassium formate then reacts with water to form $\mathrm{H}_{2}$. However, further decomposition of $\mathrm{KHCO}_{3}$ leads to the formation of additional $\mathrm{CO}_{2}$, which is also confirmed by the experimental results. $\mathrm{CO}_{2}$ concentrations increased by $16-54 \%$ (depending on biomass and catalyst type). At the same time, the studies $[50,98,104]$ confirm that the CO concentration significantly decreased (up to 95\%) when using potassium-containing catalysts. The reason for this is the enhancement of the water-gas shift reaction.

Lin et al. [44] studied the catalytic effect of $\mathrm{KOH}$ on the characteristics of liquid products of pyrolysis of oil sludge. The experiments were carried out in a horizontal quartz tube reactor with a fixed bed at a temperature of $600{ }^{\circ} \mathrm{C}$. With the addition of $10 \mathrm{wt} \% \mathrm{KOH}$, the liquid product yield decreased from $60.1 \%$ to $52.8 \%$. The shares of solid residues and gaseous product increased from $16.6 \%$ to $19.4 \%$ and from $23.3 \%$ to $27.8 \%$, respectively. Lin et al. [44] found that the addition of $\mathrm{KOH}$ improved the quality of the resulting oil product. Its calorific value increased by $22 \%$, and viscosity decreased significantly (up to $70 \%)$.

4.4. Summarizing the Results on Pyrolysis and Gasification of Low-Grade Liquid, Wet, and Slurry Fuels

The review of modern researches allows us to draw the following conclusions (Figure 5):

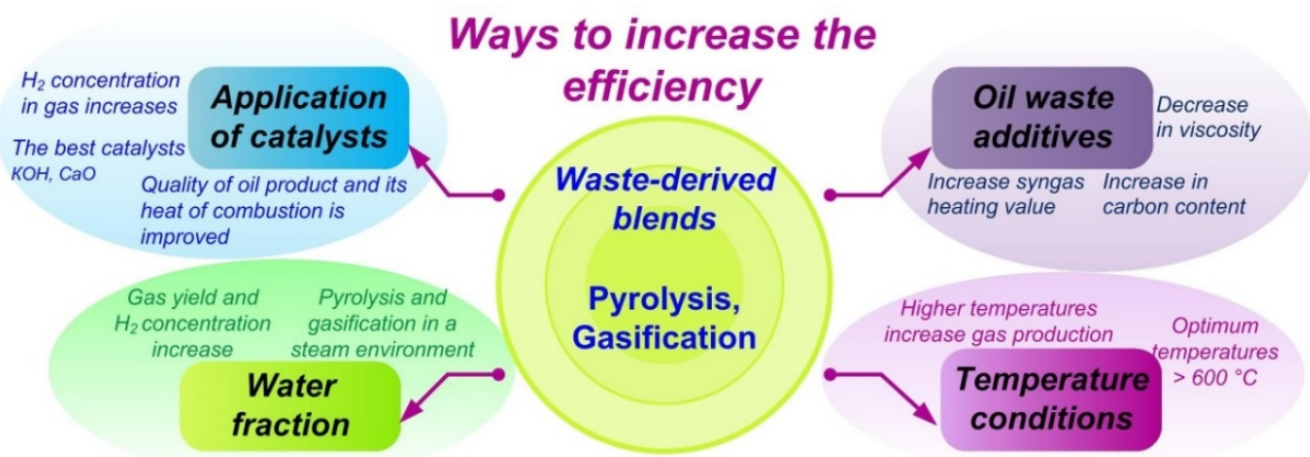

Figure 5. Features of pyrolysis and gasification of fuel slurries and blends.

(i) Petroleum waste can significantly increase the efficiency (up to 70\%) of pyrolysis and gasification of slurries due to high volatiles and carbon content, low ash content, and 
high calorific value. The use of even a small amount of petroleum-based additive (from $5 \mathrm{wt} \%$ to $20 \mathrm{wt} \%$ ) in the conventional CWS increases the carbon content without changing the fuel viscosity;

(ii) Water in slurries can positively affect the composition of the gas since gasification in a vapor medium is more effective in terms of maximizing the yield of hydrogen compared to air;

(iii) In terms of the gas yield, temperature above $600^{\circ} \mathrm{C}$ is optimal. Under these conditions, the reactions of dehydrogenation, steam reforming, and water-gas conversion are intensified. However, the choice of thermal conditions should be determined based on the purpose of the pyrolysis and gasification products.

(iv) Alkaline catalysts contribute to $\mathrm{H}_{2}$ production during pyrolysis and gasification of waste.

(v) Future research in the field of pyrolysis and gasification of slurry and mixed fuels has the following promising directions: torrefaction of components for the preparation of wet slurries; a detailed study of the influence of heating rate, residence time, and pressure of the pyrolysis and gasification.

\section{Conclusions}

(i) Almost all typical industrial and solid domestic waste has a calorific value comparable to low-grade fuels. The average calorific value of such waste is $7-12 \mathrm{MJ} / \mathrm{kg}$. As a consequence, this waste can be considered promising for energy production. This approach helps to reduce the rate of depletion of fossil fuels, expand the fuel base of many countries, and reduce their economic and energy dependence.

(ii) The combustion of waste-derived liquid, high-moisture, and slurry fuels can be efficiently implemented using boilers of various modifications such as vortex combustion chambers, boilers with burners, and nozzles for fuel injection, grate, and fluidized bed boilers.

(iii) The combustion of waste-derived fuel slurries and high-moisture fuels can be complicated by a long ignition delay time, low combustion temperature, and low specific calorific value. However, this approach provides wide possibilities for varying the composition of the mixture, atomization, increasing the completeness of fuel burnout, and reducing some hazardous emissions.

(iv) The combustion of fuel mixtures, in contrast to the combustion of individual components, provides more opportunities for stabilizing important process parameters (combustion temperature, calorific value, etc.) and obtaining synergistic benefits (for example, a significant reduction in sulfur oxide emissions).

(v) The present review of pyrolysis and gasification of waste-derived fuel slurries summarizes the main parameters influencing the optimization of the yield of gaseous products. Temperature is one of the most important factors affecting the yield and properties of the end products of pyrolysis and gasification. Optimal process temperatures in terms of maximizing gas yield are above $600{ }^{\circ} \mathrm{C}$. High temperatures and long residence times favor the formation of non-condensable gaseous products due to secondary decomposition reactions.

(vi) Pyrolysis and gasification in a steam medium are more efficient in terms of maximizing the yield of hydrogen compared to air. From this point of view, the use of watercontaining slurry fuels is a promising direction. A substantial part of the gasifier steam requirement can be covered by the generation of steam from the slurry.

(vii) The processes of pyrolysis and gasification of oil wastes in the slurry fuels is an effective option for maximizing gas and liquid products and a promising way to dispose of accumulated waste as fuel with low energy losses. This could conserve fossil fuels and solve the problem of increasing energy demand.

Author Contributions: Conceptualization, supervision, P.S.; funding acquisition, P.S.; investigation, K.V. and G.N.; writing—original draft, K.V. and G.N.; visualization, K.V. and G.N.; writing—review 
and editing, P.S., K.V. and G.N. All authors have read and agreed to the published version of the manuscript.

Funding: The research into combustion of waste was supported by a grant from the Ministry of Science and Higher Education of Russia, Agreement No. 075-15-2020-806 (Contract No 13.1902.21.0014). The research into pyrolysis and gasification were supported by the Russian Foundation for Basic Research (project No. 19-53-80019).

Conflicts of Interest: The authors declare no conflict of interest.

\section{References}

1. Li, D.; Wu, D.; Xu, F.; Lai, J.; Shao, L. Literature overview of Chinese research in the field of better coal utilization. J. Clean. Prod. 2018, 185, 959-980. [CrossRef]

2. Mallakpour, S.; Sirous, F.; Hussain, C.M. Sawdust, a versatile, inexpensive, readily available bio-waste: From mother earth to valuable materials for sustainable remediation technologies. Adv. Colloid Interface Sci. 2021, 295, 102492. [CrossRef] [PubMed]

3. Kazamias, G.; Zorpas, A.A. Drill cuttings waste management from oil \& gas exploitation industries through end-of-waste criteria in the framework of circular economy strategy. J. Clean. Prod. 2021, 322, 129098. [CrossRef]

4. Mishra, A.; Siddiqi, H.; Kumari, U.; Behera, I.D.; Mukherjee, S.; Meikap, B.C. Pyrolysis of waste lubricating oil/waste motor oil to generate high-grade fuel oil: A comprehensive review. Renew. Sustain. Energy Rev. 2021, 150, 111446. [CrossRef]

5. Zhao, R.; Dai, R.; Chen, T.; Qin, J.; Zhang, J.; Wu, J. Investigation on combustion, gaseous pollutants emission and ash characteristics during co-combustion of semicoke and coal slime. J. Environ. Chem. Eng. 2021, 9, 106249. [CrossRef]

6. Guo, Y.; Guo, F.; Zhou, L.; Guo, Z.; Miao, Z.; Liu, H.; Zhang, X.; Wu, J.; Zhang, Y. Investigation on co-combustion of coal gasification fine slag residual carbon and sawdust char blends: Physiochemical properties, combustion characteristic and kinetic behavior. Fuel 2021, 292, 120387. [CrossRef]

7. Rahman, M.M.; Rahman, S.M.; Rahman, M.S.; Hasan, M.A.; Shoaib, S.A.; Rushd, S. Greenhouse Gas Emissions from Solid Waste Management in Saudi Arabia-Analysis of Growth Dynamics and Mitigation Opportunities. Appl. Sci. 2021, 11, 1737. [CrossRef]

8. Zhou, Y.; Sun, J.; Wang, L.; Zhu, G.; Li, M.; Liu, J.; Li, Z.; Gong, H.; Wu, C.; Yin, G. Multiple classes of chemical contaminants in soil from an e-waste disposal site in China: Occurrence and spatial distribution. Sci. Total Environ. 2021, 752, 141924. [CrossRef]

9. Khan, H.M.; Iqbal, T.; Yasin, S.; Irfan, M.; Kazmi, M.; Fayaz, H.; Mujtaba, M.A.; Ali, C.H.; Kalam, M.A.; Soudagar, M.E.M.; et al. Production and utilization aspects of waste cooking oil based biodiesel in Pakistan. Alexandria Eng. J. 2021, 60, 5831-5849. [CrossRef]

10. Furubayashi, T.; Nakata, T. Analysis of woody biomass utilization for heat, electricity, and CHP in a regional city of Japan. $J$. Clean. Prod. 2021, 290, 125665. [CrossRef]

11. Wang, Y.; Jia, L.; Guo, J.; Wang, B.; Zhang, L.; Xiang, J.; Jin, Y. Thermogravimetric analysis of co-combustion between municipal sewage sludge and coal slime: Combustion characteristics, interaction and kinetics. Thermochim. Acta 2021, 706, 179056. [CrossRef]

12. United Nations. The Paris Agreement, FCCC/CP/2015/L.9/Rev.1; United Nations: New York, NY, USA, 2015.

13. Kaza, S.; Yao, L.C.; Bhada-Tata, P.; Van Woerden, F. What a Waste 2.0: A Global Snapshot of Solid Waste Management to 2050; World Bank: Washington, DC, USA, 2018; ISBN 978-1-4648-1329-0.

14. Habib, M.A.; Ahmed, M.M.; Aziz, M.; Beg, M.R.A.; Hoque, M.E. Municipal Solid Waste Management and Waste-to-Energy Potential from Rajshahi City Corporation in Bangladesh. Appl. Sci. 2021, 11, 3744. [CrossRef]

15. Ding, Y.; Zhao, J.; Liu, J.W.; Zhou, J.; Cheng, L.; Zhao, J.; Shao, Z.; Iris, Ç.; Pan, B.; Li, X.; et al. A review of China's municipal solid waste (MSW) and comparison with international regions: Management and technologies in treatment and resource utilization. J. Clean. Prod. 2021, 293, 126144. [CrossRef]

16. Sun, Y.; Qin, Z.; Tang, Y.; Huang, T.; Ding, S.; Ma, X. Techno-environmental-economic evaluation on municipal solid waste (MSW) to power/fuel by gasification-based and incineration-based routes. J. Environ. Chem. Eng. 2021, 9, 106108. [CrossRef]

17. Wei, C.; Yu, Z.; Zhang, X.; Ma, X. Co-combustion behavior of municipal solid waste and food waste anaerobic digestates: Combustion performance, kinetics, optimization, and gaseous products. J. Environ. Chem. Eng. 2021, 9, 106028. [CrossRef]

18. Yang, W.; Pudasainee, D.; Gupta, R.; Li, W.; Wang, B.; Sun, L. An overview of inorganic particulate matter emission from coal/biomass/MSW combustion: Sampling and measurement, formation, distribution, inorganic composition and influencing factors. Fuel Process. Technol. 2021, 213, 106657. [CrossRef]

19. Holubčík, M.; Klačková, I.; Durčanský, P. Pyrolysis Conversion of Polymer Wastes to Noble Fuels in Conditions of the Slovak Republic. Energies 2020, 13, 4849. [CrossRef]

20. Bala-Litwiniak, A.; Radomiak, H. Possibility of the Utilization of Waste Glycerol as an Addition to Wood Pellets. Waste Biomass Valoriz. 2019, 10, 2193-2199. [CrossRef]

21. Dudyński, M.; Dudyński, K.; Kluska, J.; Ochnio, M.; Kazimierski, P.; Kardaś, D. Gasification of leather waste for energy production: Laboratory scale and industrial tests. Int. J. Energy Res. 2021, 45, 18540-18553. [CrossRef]

22. Rueda-Avellaneda, J.F.; Rivas-García, P.; Gomez-Gonzalez, R.; Benitez-Bravo, R.; Botello-Álvarez, J.E.; Tututi-Avila, S. Current and prospective situation of municipal solid waste final disposal in Mexico: A spatio-temporal evaluation. Renew. Sustain. Energy Transit. 2021, 1, 100007. [CrossRef] 
23. Shahnazari, A.; Rafiee, M.; Rohani, A.; Bhushan Nagar, B.; Ebrahiminik, M.A.; Aghkhani, M.H. Identification of effective factors to select energy recovery technologies from municipal solid waste using multi-criteria decision making (MCDM): A review of thermochemical technologies. Sustain. Energy Technol. Assess. 2020, 40, 100737. [CrossRef]

24. Kumar, A.; Sah, B.; Singh, A.R.; Deng, Y.; He, X.; Kumar, P.; Bansal, R.C. A review of multi criteria decision making (MCDM) towards sustainable renewable energy development. Renew. Sustain. Energy Rev. 2017, 69, 596-609. [CrossRef]

25. Tong, C.; Yang, X.; Chen, G.; Zhang, Y.; Chen, L.; Zhou, Y.; He, T.; Jin, B. Experimental investigation for the combustion characteristics of blends of three kinds of coal. Fuel 2021, 300, 120937. [CrossRef]

26. Yang, X.; Luo, Z.; Liu, X.; Yu, C.; Li, Y.; Ma, Y. Experimental and numerical investigation of the combustion characteristics and $\mathrm{NO}$ emission behaviour during the co-combustion of biomass and coal. Fuel 2021, 287, 119383. [CrossRef]

27. Paraschiv, L.S.; Serban, A.; Paraschiv, S. Calculation of combustion air required for burning solid fuels (coal/biomass/solid waste) and analysis of flue gas composition. Energy Rep. 2020, 6, 36-45. [CrossRef]

28. Quesada, L.; Pérez, A.; Godoy, V.; Peula, F.J.; Calero, M.; Blázquez, G. Optimization of the pyrolysis process of a plastic waste to obtain a liquid fuel using different mathematical models. Energy Convers. Manag. 2019, 188, 19-26. [CrossRef]

29. Su, G.; Ong, H.C.; Mofijur, M.; Mahlia, T.M.I.; Ok, Y.S. Pyrolysis of waste oils for the production of biofuels: A critical review. J. Hazard. Mater. 2022, 424, 127396. [CrossRef] [PubMed]

30. Ferraz de Campos, V.A.; Silva, V.B.; Cardoso, J.S.; Brito, P.S.; Tuna, C.E.; Silveira, J.L. A review of waste management in Brazil and Portugal: Waste-to-energy as pathway for sustainable development. Renew. Energy 2021, 178, 802-820. [CrossRef]

31. Shahbaz, M.; AlNouss, A.; Ghiat, I.; Mckay, G.; Mackey, H.; Elkhalifa, S.; Al-Ansari, T. A comprehensive review of biomass based thermochemical conversion technologies integrated with $\mathrm{CO}_{2}$ capture and utilisation within BECCS networks. Resour. Conserv. Recycl. 2021, 173, 105734. [CrossRef]

32. Dufour, A. Thermochemical Conversion of Biomass for Energy and Chemicals Production; John Wiley \& Sons: Hoboken, NJ, USA, 2016; pp. 1-160. [CrossRef]

33. Mammino, L. Biomass Burning in Sub-Saharan Africa: Chemical Issues and Action Outreach; Springer: Dordrecht, The Netherlands, 2020.

34. International Energy Agency. Key World Energy Statistics (Statistics Report); International Energy Agency: Paris, France, 2020.

35. Junginger, M.; Goh, C.S.; Faaij, A. International Bioenergy Trade: History, Status \& Outlook on Securing Sustainable Bioenergy Supply, Demand and Markets; Springer: Dordrecht, The Netherlands, 2014.

36. David, C. Wilson Global Waste Management Outlook 2015; International Solid Waste Association General Secretariat: Vienna, Austria, 2015.

37. World Energy Council. World Energy Resources; World Energy Council: London, UK, 2016.

38. Li, D.; Liu, J.; Wang, S.; Cheng, J. Study on coal water slurries prepared from coal chemical wastewater and their industrial application. Appl. Energy 2020, 268, 114976. [CrossRef]

39. Lázaro, M.J.; Moliner, R.; Suelves, I.; Domeo, C.; Nerín, C. Co-pyrolysis of a mineral waste oil/coal slurry in a continuous-mode fluidized bed reactor. J. Anal. Appl. Pyrolysis 2002, 65, 239-252. [CrossRef]

40. Yang, Z.; Zhang, Y.; Liu, L.; Wang, X.; Zhang, Z. Environmental investigation on co-combustion of sewage sludge and coal gangue: $\mathrm{SO}_{2}, \mathrm{NO}_{x}$ and trace elements emissions. Waste Manag. 2016, 50, 213-221. [CrossRef] [PubMed]

41. Glushkov, D.O.; Paushkina, K.K.; Shabardin, D.P. Co-combustion of coal processing waste, oil refining waste and municipal solid waste: Mechanism, characteristics, emissions. Chemosphere 2020, 240, 124892. [CrossRef] [PubMed]

42. Vershinina, K.Y.; Strizhak, P.A. Ignition of coal suspensions based on water of different quality. Coke Chem. 2016, 59, 437-440. [CrossRef]

43. Zhao, Z.; Wang, R.; Ge, L.; Wu, J.; Yin, Q.; Wang, C. Energy utilization of coal-coking wastes via coal slurry preparation: The characteristics of slurrying, combustion, and pollutant emission. Energy 2019, 168, 609-618. [CrossRef]

44. Lin, B.; Wang, J.; Huang, Q.; Chi, Y. Effects of potassium hydroxide on the catalytic pyrolysis of oily sludge for high-quality oil product. Fuel 2017, 200, 124-133. [CrossRef]

45. Zou, H.; Liu, C.; Evrendilek, F.; He, Y.; Liu, J. Evaluation of reaction mechanisms and emissions of oily sludge and coal co-combustions in $\mathrm{O}_{2} / \mathrm{CO}_{2}$ and $\mathrm{O}_{2} / \mathrm{N}_{2}$ atmospheres. Renew. Energy 2021, 171, 1327-1343. [CrossRef]

46. Wang, J.; Zhang, B.; Zhong, Z.; Ding, K.; Deng, A.; Min, M.; Chen, P.; Ruan, R. Catalytic fast co-pyrolysis of bamboo residual and waste lubricating oil over an ex-situ dual catalytic beds of MgO and HZSM-5: Analytical PY-GC/MS study. Energy Convers. Manag. 2017, 139, 222-231. [CrossRef]

47. Staroń, A.; Kowalski, Z.; Staroń, P.; Banach, M. Studies on CWL with glycerol for combustion process. Environ. Sci. Pollut. Res. 2019, 26, 2835-2844. [CrossRef]

48. Bae, J.S.; Lee, D.W.; Park, S.J.; Lee, Y.J.; Hong, J.C.; Ra, H.W.; Han, C.; Choi, Y.C. High-pressure gasification of coal water ethanol slurry in an entrained flow gasifier for bioethanol application. Energy Fuels 2012, 26, 6033-6039. [CrossRef]

49. Boumanchar, I.; Chhiti, Y.; M’hamdi Alaoui, F.E.; Elkhouakhi, M.; Sahibed-dine, A.; Bentiss, F.; Jama, C.; Bensitel, M. Investigation of (co)-combustion kinetics of biomass, coal and municipal solid wastes. Waste Manag. 2019, 97, 10-18. [CrossRef] [PubMed]

50. Lam, S.S.; Tsang, Y.F.; Yek, P.N.Y.; Liew, R.K.; Osman, M.S.; Peng, W.; Lee, W.H.; Park, Y.K. Co-processing of oil palm waste and waste oil via microwave co-torrefaction: A waste reduction approach for producing solid fuel product with improved properties. Process Saf. Environ. Prot. 2019, 128, 30-35. [CrossRef]

51. Sukiran, M.A.; Abnisa, F.; Wan Daud, W.M.A.; Abu Bakar, N.; Loh, S.K. A review of torrefaction of oil palm solid wastes for biofuel production. Energy Convers. Manag. 2017, 149, 101-120. [CrossRef] 
52. Bach, Q.V.; Trinh, T.N.; Tran, K.Q.; Thi, N.B.D. Pyrolysis characteristics and kinetics of biomass torrefied in various atmospheres. Energy Convers. Manag. 2017, 141, 72-78. [CrossRef]

53. Medic, D.; Darr, M.; Shah, A.; Potter, B.; Zimmerman, J. Effects of torrefaction process parameters on biomass feedstock upgrading. Fuel 2012, 91, 147-154. [CrossRef]

54. Cheng, Z.; Jin, H.; Liu, S.; Guo, L.; Xu, J.; Su, D. Hydrogen production by semicoke gasification with a supercritical water fluidized bed reactor. Int. J. Hydrogen Energy 2016, 41, 16055-16063. [CrossRef]

55. Gaber, C.; Wachter, P.; Demuth, M.; Hochenauer, C. Experimental investigation and demonstration of pilot-scale combustion of oil-water emulsions and coal-water slurry with pronounced water contents at elevated temperatures with the use of pure oxygen. Fuel 2020, 282, 118692. [CrossRef]

56. Zhang, H.; Gao, Z.; Ao, W.; Li, J.; Liu, G.; Fu, J.; Ran, C.; Mao, X.; Kang, Q.; Liu, Y.; et al. Microwave-assisted pyrolysis of textile dyeing sludge using different additives. J. Anal. Appl. Pyrolysis 2017, 127, 140-149. [CrossRef]

57. Staroń, A.; Banach, M.; Kowalski, Z.; Staroń, P. Impact of waste soot on properties of coal-water suspensions. J. Clean. Prod. 2016, 135, 457-467. [CrossRef]

58. Zhao, X.; Zhu, W.; Huang, J.; Li, M.; Gong, M. Emission characteristics of PCDD/Fs, PAHs and PCBs during the combustion of sludge-coal water slurry. J. Energy Inst. 2015, 88, 105-111. [CrossRef]

59. Fu, B.; Liu, G.; Mian, M.M.; Zhou, C.; Sun, M.; Wu, D.; Liu, Y. Co-combustion of industrial coal slurry and sewage sludge: Thermochemical and emission behavior of heavy metals. Chemosphere 2019, 233, 440-451. [CrossRef] [PubMed]

60. Kuan, Y.H.; Wu, F.H.; Chen, G.B.; Lin, H.T.; Lin, T.H. Study of the combustion characteristics of sewage sludge pyrolysis oil, heavy fuel oil, and their blends. Energy 2020, 201, 117559. [CrossRef]

61. Luo, Z.; Xu, D.; Ma, Y.; Cheng, Q. Experimental Study on Co-Firing of Coal and Brewery Wastewater Sludge. Appl. Sci. 2020, 10, 7589. [CrossRef]

62. Wan, G.; Yu, J.; Wang, X.; Sun, L. Study on the pyrolysis behavior of coal-water slurry and coal-oil-water slurry. J. Energy Inst. 2022, 100, 10-21. [CrossRef]

63. Moliner, R.; Lázaro, M.; Suelves, I. Valorization of Lube Oil Waste by Pyrolysis. Energy Fuels 1997, 11, 1165-1170. [CrossRef]

64. Tamošiūnas, A.; Gimžauskaitè, D.; Aikas, M.; Uscila, R.; Praspaliauskas, M.; Eimontas, J. Gasification of Waste Cooking Oil to Syngas by Thermal Arc Plasma. Energies 2019, 12, 2612. [CrossRef]

65. Feng, C.; Wu, H. Synergy on particulate matter emission during the combustion of bio-oil/biochar slurry (bioslurry). Fuel 2018, 214, 546-553. [CrossRef]

66. Zhou, H.; Li, Y.; Li, N.; Cen, K. Experimental investigation of ignition and combustion characteristics of single coal and biomass particles in $\mathrm{O}_{2} / \mathrm{N}_{2}$ and $\mathrm{O}_{2} / \mathrm{H}_{2} \mathrm{O}$. J. Energy Inst. 2019, 92, 502-511. [CrossRef]

67. D’Jesús, P.; Boukis, N.; Kraushaar-Czarnetzki, B.; Dinjus, E. Gasification of corn and clover grass in supercritical water. Fuel 2006, 85, 1032-1038. [CrossRef]

68. Malika, A.; Mohammed, A.; Guhel, Y. Energetic Combustion Characteristics and Environmental Impact of Moroccan Biomass Wastes and Their Solid Biofuel. Waste Biomass Valoriz. 2019, 10, 1311-1322. [CrossRef]

69. Variny, M.; Varga, A.; Rimár, M.; Janošovský, J.; Kizek, J.; Lukáč, L.; Jablonský, G.; Mierka, O. Advances in Biomass Co-Combustion with Fossil Fuels in the European Context: A Review. Processes 2021, 9, 100. [CrossRef]

70. Khan, A.A.; de Jong, W.; Jansens, P.J.; Spliethoff, H. Biomass combustion in fluidized bed boilers: Potential problems and remedies. Fuel Process. Technol. 2009, 90, 21-50. [CrossRef]

71. Xinjie, L.; Shihong, Z.; Xincheng, W.; Jinai, S.; Xiong, Z.; Xianhua, W.; Haiping, Y.; Hanping, C. Co-combustion of wheat straw and camphor wood with coal slime: Thermal behaviour, kinetics, and gaseous pollutant emission characteristics. Energy 2021, 234, 121292. [CrossRef]

72. Seepana, S.; Arumugam, S.; Sivaramakrishnan, K.; Muthukrishnan, M. Evaluation of feasibility of pelletized wood co-firing with high ash Indian coals. J. Energy Inst. 2018, 91, 1126-1135. [CrossRef]

73. Johansson, A.-C.; Molinder, R.; Vikström, T.; Wiinikka, H. Particle formation during suspension combustion of different biomass powders and their fast pyrolysis bio-oils and biochars. Fuel Process. Technol. 2021, 218, 106868. [CrossRef]

74. Skoglund, N.; Bäfver, L.; Fahlström, J.; Holmén, E.; Renström, C. Fuel design in co-combustion of demolition wood chips and municipal sewage sludge. Fuel Process. Technol. 2016, 141, 196-201. [CrossRef]

75. Jianzhong, L.; Ruikun, W.; Jianfei, X.; Junhu, Z.; Kefa, C. Pilot-scale investigation on slurrying, combustion, and slagging characteristics of coal slurry fuel prepared using industrial wasteliquid. Appl. Energy 2014, 115, 309-319. [CrossRef]

76. Liu, Q.; Zhong, W.; Yu, A.; Wang, C.-H. Co-firing of coal and biomass under pressurized oxy-fuel combustion mode: Experimental test in a $10 \mathrm{~kW}_{\text {th }}$ fluidized bed. Chem. Eng. J. 2021, 431 Pt 4, 133457. [CrossRef]

77. Hamadeh, H.; Toor, S.Y.; Douglas, P.L.; Sarathy, S.M.; Dibble, R.W.; Croiset, E. Techno-Economic Analysis of Pressurized Oxy-Fuel Combustion of Petroleum Coke. Energies 2020, 13, 3463. [CrossRef]

78. Chansa, O.; Luo, Z.; Yu, C. Study of the kinetic behaviour of biomass and coal during oxyfuel co-combustion. Chin. J. Chem. Eng. 2020, 28, 1796-1804. [CrossRef]

79. Chen, C.; Yang, S. The energy demand and environmental impacts of oxy-fuel combustion vs. post-combustion capture in China. Energy Strategy Rev. 2021, 38, 100701. [CrossRef]

80. Huang, X.; Guo, J.; Liu, Z.; Zheng, C. Opportunities and Challenges of Oxy-Fuel Combustion. In Oxy-Fuel Combustion; Academic Press: Cambridge, MA, USA, 2018; pp. 1-12. [CrossRef] 
81. Feng, P.; Li, X.; Wang, J.; Li, J.; Wang, H.; He, L. The mixtures of bio-oil derived from different biomass and coal/char as biofuels: Combustion characteristics. Energy 2021, 224, 120132. [CrossRef]

82. Lei, K.; Zhang, R.; Ye, B.Q.; Cao, J.; Liu, D. Study of Sewage Sludge/Coal Co-Combustion by Thermogravimetric Analysis and Single Particle Co-Combustion Method. Energy Fuels 2018, 32, 6300-6308. [CrossRef]

83. Guo, Y.; Wu, J.; Jia, W.; Guo, F.; Qiu, G.; Wang, R.; Zhang, Y.; Dai, B. Evaluation of the thermal behavior, synergistic catalysis, and pollutant emissions during the co-combustion of sewage sludge and coal gasification fine slag residual carbon. Catalysts 2021, 11, 1142. [CrossRef]

84. Van Grinsven, A.; van den Toorn, E.; van der Veen, R.; Kampman, B. Used Cooking Oil (UCO) as Biofuel Feedstock in the EU; CE Delft: Delft, Netherlands, 2020.

85. Gad, M.S.; Mahfouz, A.; Emara, A. Spray and combustion characteristics for light diesel/waste cooking oils blended with fuel additives inside an industrial boiler. Fuel 2021, 286, 119247. [CrossRef]

86. Chen, C.Y.; Lee, W.J.; Mwangi, J.K.; Wang, L.C.; Wu, J.L.; Lin, S.L. Reduction of persistent organic pollutant emissions during incinerator start-up by using crude waste cooking oil as an alternative fuel. Aerosol Air Qual. Res. 2017, 17, 899-912. [CrossRef]

87. Ortner, M.E.; Müller, W.; Schneider, I.; Bockreis, A. Environmental assessment of three different utilization paths of waste cooking oil from households. Resour. Conserv. Recycl. 2016, 106, 59-67. [CrossRef]

88. Hong, F.; Yan, G.; Gao, M. The operation control and application of CFB boiler unit with high blending ratio of coal slurry. Control Eng. Pract. 2019, 85, 80-89. [CrossRef]

89. Wang, Y.; Cao, M.; Wang, Z.; Wei, L.; Zhao, S. A novel suspension-floating-circulating fluidized combustion technology for coal slurry. Int. J. Coal Sci. Technol. 2016, 3, 35-46. [CrossRef]

90. Burra, K.G.; Gupta, A.K. Thermochemical Reforming of Wastes to Renewable Fuels. In Energy for Propulsion; Springer: Singapore, 2018; pp. 395-428. [CrossRef]

91. Li, W.; He, S.; Li, S. Experimental Study and Thermodynamic Analysis of Hydrogen Production through a Two-Step Chemical Regenerative Coal Gasification. Appl. Sci. 2019, 9, 3035. [CrossRef]

92. Heinze, C.; Langner, E.; May, J.; Epple, B. Determination of a Complete Conversion Model for Gasification of Lignite Char. Appl. Sci. 2020, 10, 1916. [CrossRef]

93. Ding, L.; Dai, Z.; Guo, Q.; Yu, G. Effects of in-situ interactions between steam and coal on pyrolysis and gasification characteristics of pulverized coals and coal water slurry. Appl. Energy 2017, 187, 627-639. [CrossRef]

94. Efika, C.E.; Onwudili, J.A.; Williams, P.T. Influence of heating rates on the products of high-temperature pyrolysis of waste wood pellets and biomass model compounds. Waste Manag. 2018, 76, 497-506. [CrossRef]

95. Sikarwar, V.S.; Zhao, M.; Clough, P.; Yao, J.; Zhong, X.; Memon, M.Z.; Shah, N.; Anthony, E.J.; Fennell, P.S. An overview of advances in biomass gasification. Energy Environ. Sci. 2016, 9, 2939-2977. [CrossRef]

96. Nguyen, N.M.; Alobaid, F.; Dieringer, P.; Epple, B. Biomass-Based Chemical Looping Gasification: Overview and Recent Developments. Appl. Sci. 2021, 11, 7069. [CrossRef]

97. Neves, D.; Thunman, H.; Matos, A.; Tarelho, L.; Gómez-Barea, A. Characterization and prediction of biomass pyrolysis products. Prog. Energy Combust. Sci. 2011, 37, 611-630. [CrossRef]

98. Sato, T.; Kurosawa, S.; Smith, R.L.; Adschiri, T.; Arai, K. Water gas shift reaction kinetics under noncatalytic conditions in supercritical water. J. Supercrit. Fluids 2004, 29, 113-119. [CrossRef]

99. Svoboda, K.; Pohořelý, M.; Jeremiáš, M.; Kameníková, P.; Hartman, M.; Skoblja, S.; Šyc, M. Fluidized bed gasification of coal-oil and coal-water-oil slurries by oxygen-steam and oxygen- $\mathrm{CO}_{2}$ mixtures. Fuel Process. Technol. 2012, 95, 16-26. [CrossRef]

100. Feng, P.; Lin, W.; Jensen, P.A.; Song, W.; Hao, L.; Raffelt, K.; Dam-Johansen, K. Entrained flow gasification of coal/bio-oil slurries. Energy 2016, 111, 793-802. [CrossRef]

101. Liu, W.; Yuan, H. Simultaneous production of hydrogen and carbon nanotubes from cracking of a waste cooking oil model compound over Ni-Co/SBA-15 catalysts. Int. J. Energy Res. 2020, 44, 11564-11582. [CrossRef]

102. Kruse, A.; Meier, D.; Rimbrecht, P.; Schacht, M. Gasification of Pyrocatechol in Supercritical Water in the Presence of Potassium Hydroxide. Ind. Eng. Chem. Res. 2000, 39, 4842-4848. [CrossRef]

103. Song, G.; Huang, D.; Li, H.; Wang, X.; Ren, Q.; Jiang, L.; Wang, Y.; Su, S.; Hu, S.; Xiang, J. Pyrolysis reaction mechanism of typical Chinese agriculture and forest waste pellets at high heating rates based on the photo-thermal TGA. Energy 2022, $244,123164$. [CrossRef]

104. Morf, P.; Hasler, P.; Nussbaumer, T. Mechanisms and kinetics of homogeneous secondary reactions of tar from continuous pyrolysis of wood chips. Fuel 2002, 81, 843-853. [CrossRef]

105. Xie, Q.; Peng, P.; Liu, S.; Min, M.; Cheng, Y.; Wan, Y.; Li, Y.; Lin, X.; Liu, Y.; Chen, P.; et al. Fast microwave-assisted catalytic pyrolysis of sewage sludge for bio-oil production. Bioresour. Technol. 2014, 172, 162-168. [CrossRef]

106. Shen, L.; Zhang, D.K. An experimental study of oil recovery from sewage sludge by low-temperature pyrolysis in a fluidised-bed. Fuel 2003, 82, 465-472. [CrossRef]

107. Nie, F.; He, D.; Guan, J.; Zhang, K.; Meng, T.; Zhang, Q. The influence of abundant calcium oxide addition on oil sand pyrolysis. Fuel Process. Technol. 2017, 155, 216-224. [CrossRef]

108. Sinag, A.; Kruse, A.; Schwarzkopf, V. Key Compounds of the Hydropyrolysis of Glucose in Supercritical Water in the Presence of $\mathrm{K}_{2} \mathrm{CO}_{3}$. Ind. Eng. Chem. Res. 2003, 42, 3516-3521. [CrossRef] 